Supporting Information

\title{
Tris(pyrazolyl)methanide Complexes of Trivalent Rare-Earth Metals
}

Tengfei Li,${ }^{\dagger}$ Guangchao Zhang, ${ }^{\dagger}$ JingJing Guo,${ }^{\dagger}$ Shaowu Wang, ${ }^{\star}$ Xuebing Leng, and Yaofeng Chen ${ }^{*}$

${ }^{\dagger}$ State Key Laboratory of Organometallic Chemistry, Shanghai Institute of Organic Chemistry, Chinese Academy of Sciences, 345 Lingling Road, Shanghai 200032, P. R. China

${ }^{\star}$ Key Laboratory of Functional Molecular Solids, Ministry of Education, Anhui Laboratory of Molecule-Based Materials, College of Chemistry and Materials Science, Anhui Normal University, Wuhu, Anhui 241000, P. R. China

\section{Table of Contents}

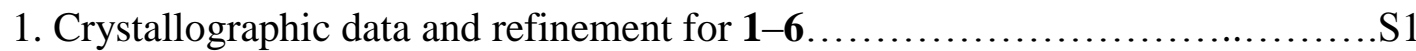

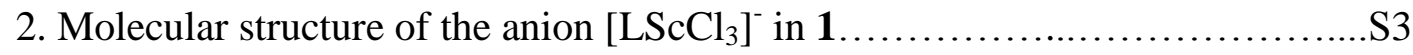

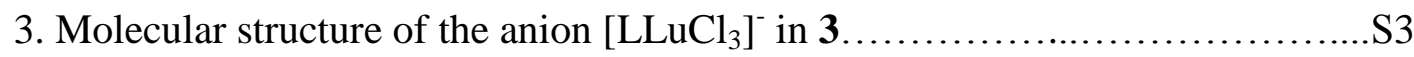

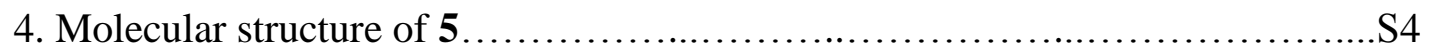

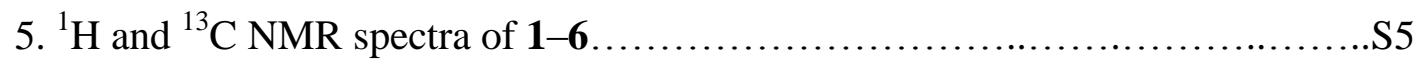

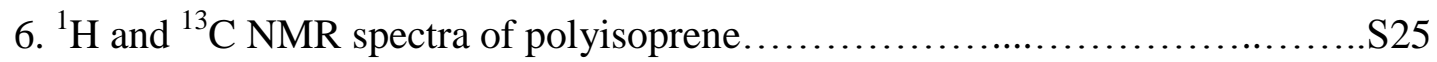


Table S1. Crystallographic Data and Refinement for 1-6.

\begin{tabular}{|c|c|c|c|}
\hline & 1 & 2 & 3 \\
\hline formula & $\mathrm{C}_{32} \mathrm{H}_{53} \mathrm{Cl}_{3} \mathrm{LiN}_{6} \mathrm{O}_{4} \mathrm{Sc}$ & $\mathrm{C}_{32} \mathrm{H}_{53} \mathrm{Cl}_{3} \mathrm{LiN}_{6} \mathrm{O}_{4} \mathrm{Y}$ & $\mathrm{C}_{32} \mathrm{H}_{53} \mathrm{Cl}_{3} \mathrm{LiN}_{6} \mathrm{O}_{4} \mathrm{Lu}$ \\
\hline fw & 744.05 & 788.00 & 874.06 \\
\hline color & brown & brick-red & brick-red \\
\hline cryst syst. & trigonal & trigonal & trigonal \\
\hline space group & $R 3 c$ & $R 3 c$ & $R 3 c$ \\
\hline$a, \AA$ & $12.5688(12)$ & $12.554(3)$ & $12.5731(12)$ \\
\hline$b, \AA$ & $12.5688(12)$ & $12.554(3)$ & $12.5731(12)$ \\
\hline$c, \AA$ & $43.147(5)$ & $43.637(11)$ & $43.468(4)$ \\
\hline$\alpha, \operatorname{deg}$ & 90 & 90 & 90 \\
\hline$\beta$, deg & 90 & 90 & 90 \\
\hline$\gamma, \operatorname{deg}$ & 120 & 120 & 120 \\
\hline$V, \AA^{3}$ & $5903.0(10)$ & $5956(3)$ & $5950.9(13)$ \\
\hline $\mathrm{Z}$ & 6 & 6 & 6 \\
\hline$D_{\text {calcd }},\left(\mathrm{mg} / \mathrm{m}^{3}\right)$ & 1.256 & 1.318 & 1.463 \\
\hline$F(000)$ & 2364 & 2472 & 2664 \\
\hline$T(\mathrm{~K})$ & $130(2)$ & $130(2)$ & $133(2)$ \\
\hline$\theta$ range, deg & $2.10,30.74$ & $2.09,27.60$ & $2.092,30.765$ \\
\hline no. of refns collected & 18932 & 15020 & 18902 \\
\hline no. of unique refns & 3524 & 3030 & 4113 \\
\hline $\begin{array}{l}\text { no. of obsd refns }(I> \\
2 \sigma(I))\end{array}$ & 2870 & 2093 & 3059 \\
\hline No. of params & 162 & 162 & 166 \\
\hline Final $R, R_{w}(I>2 \sigma(I))$ & $0.0612,0.1735$ & $0.0587,0.1414$ & $0.0280,0.0721$ \\
\hline Goodness-of-fit on $F^{2}$ & 1.061 & 1.009 & 0.962 \\
\hline$\Delta \rho_{\max , \min }, \mathrm{e} \AA^{-3}$ & $0.593,-0.490$ & $0.559,-0.512$ & $0.761,-0.506$ \\
\hline
\end{tabular}




\begin{tabular}{|c|c|c|c|}
\hline & 4 & 5 & 6 \\
\hline formula & $\mathrm{C}_{28} \mathrm{H}_{51} \mathrm{~N}_{6} \mathrm{OSi}_{2} \mathrm{Y}$ & $\mathrm{C}_{28} \mathrm{H}_{51} \mathrm{~N}_{6} \mathrm{OSi}_{2} \mathrm{Lu}$ & $\mathrm{C}_{46} \mathrm{H}_{66} \mathrm{~N}_{16} \mathrm{SiLu}_{2}$ \\
\hline fw & 632.84 & 718.89 & 1221.14 \\
\hline color & yellow & yellow & orange \\
\hline cryst syst. & monoclinic & monoclinic & orthorhombic \\
\hline space group & $P 2_{1} / c$ & $P 2_{1} / c$ & Pmmn \\
\hline$a, \AA$ & $11.8719(19)$ & $11.8087(8)$ & $13.8939(13)$ \\
\hline$b, \AA$ & $14.452(2)$ & $14.4867(10)$ & $17.3468(17)$ \\
\hline$c, \AA$ & 21.102(3) & $21.0202(14)$ & $11.7131(11)$ \\
\hline$\alpha, \operatorname{deg}$ & 90 & 90 & 90 \\
\hline$\beta, \operatorname{deg}$ & 106.097(3) & $105.7480(10)$ & 90 \\
\hline$\gamma, \operatorname{deg}$ & 90 & 90 & 90 \\
\hline$V, \AA^{3}$ & $3478.6(10)$ & $3460.9(4)$ & $2823.0(5)$ \\
\hline $\mathrm{Z}$ & 4 & 4 & 2 \\
\hline$D_{\text {calcd }},\left(\mathrm{mg} / \mathrm{m}^{3}\right)$ & 1.208 & 1.380 & 1.435 \\
\hline$F(000)$ & 1344 & 1472 & 1218 \\
\hline$T(\mathrm{~K})$ & $130(2)$ & $130(2)$ & $296(2)$ \\
\hline$\theta$ range, deg & $1.73,27.59$ & $1.729,30.579$ & $1.878,30.581$ \\
\hline no. of refns collected & 28060 & 34456 & 28626 \\
\hline no. of unique refns & 7984 & 10616 & 4619 \\
\hline no. of obsd refns $(I>2 \sigma(I))$ & 4857 & 7976 & 3832 \\
\hline No. of params & 355 & 355 & 222 \\
\hline Final $R, R_{w}(I>2 \sigma(I))$ & $0.0564,0.1140$ & $0.0323,0.0637$ & $0.0434,0.1111$ \\
\hline Goodness-of-fit on $F^{2}$ & 1.006 & 1.008 & 1.069 \\
\hline$\Delta \rho_{\max , \min }, \mathrm{e}^{-3}$ & $0.538,-0.574$ & $1.348,-1.053$ & $2.058,-3.135$ \\
\hline
\end{tabular}




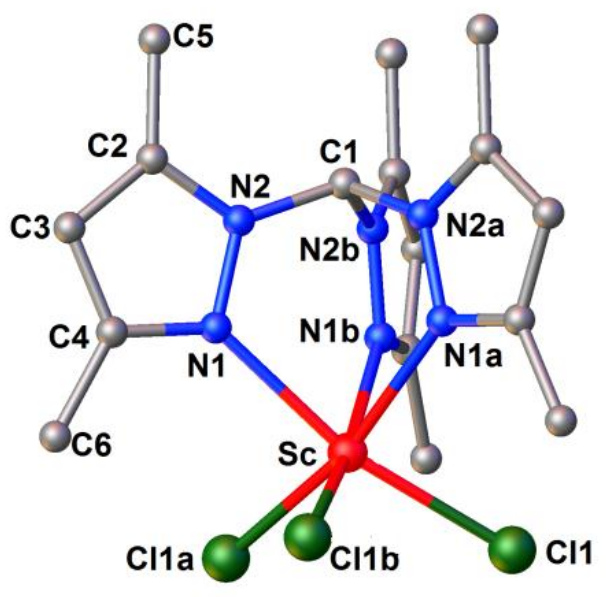

Figure S1. Molecular structure of the anion $\left[\mathrm{LScCl}_{3}\right]^{-}$in $\mathbf{1}$ (the ball and stick representation). Hydrogen atoms were omitted for clarity. Selected bond distances $[\AA]$ and angles [deg]: Sc-N1 2.284(3), Sc-Cl1 2.431(1), C1-N2 1.443(3), N1-N2 1.375(4), N2-C1-N2a 109.8(2), N1-Sc-N1a 79.1(1), Cl1-Sc-Cl1a 97.85(5).

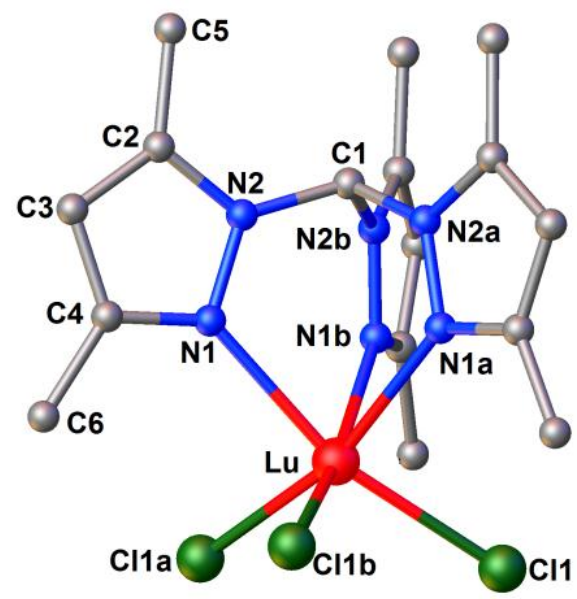

Figure S2. Molecular structure of the anion $\left[\mathrm{LLuCl}_{3}\right]^{-}$in $\mathbf{3}$ (the ball and stick

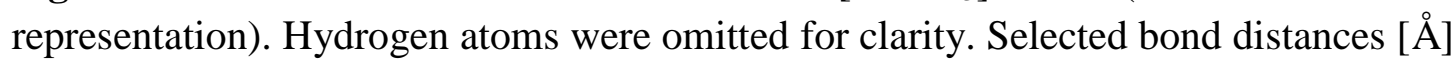
and angles [deg]: $\mathrm{Lu}-\mathrm{N} 1$ 2.380(5), Lu-Cl1 2.5320(16), C1-N2 1.440(5), N1-N2 1.384(6), N2-C1-N2a 109.7(4), N1-Lu-N1a 76.9(2), C11-Lu-Cl1A 99.26(6). 


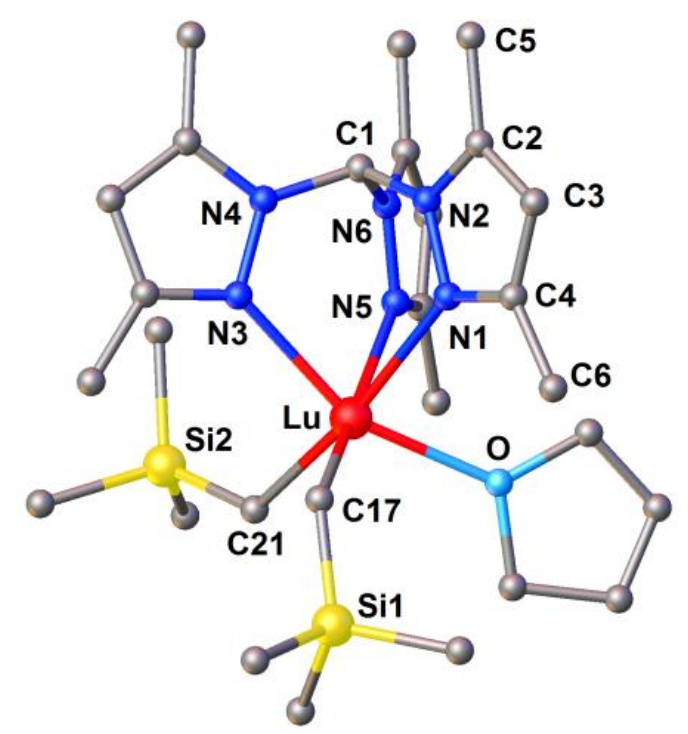

Figure S3. Molecular structure of complex 5 (ball-and-stick representation). Hydrogen atoms were omitted for clarity. Selected bond distances $[\AA]$ and angles [deg]: Lu-N1 2.433(2), Lu-N3 2.360(2), Lu-N5 2.426(2), Lu-C17 2.364(3), $\mathrm{Lu}-\mathrm{C} 21$ 2.371(3), $\mathrm{Lu}-\mathrm{O}$ 2.304(2), C1-N2 1.438(4), C1-N4 1.446(4), C1-N6 1.444(3), N2-C1-N4 109.8(2), N2-C1-N6 110.4(2), N4-C1-N6 110.2(2), $\mathrm{N} 1-\mathrm{Lu}-\mathrm{N} 3$ 76.95(8), N1-Lu-N5 73.92(8), N3-Lu-N5 79.95(8), C17-Lu-C21 100.6(1). 

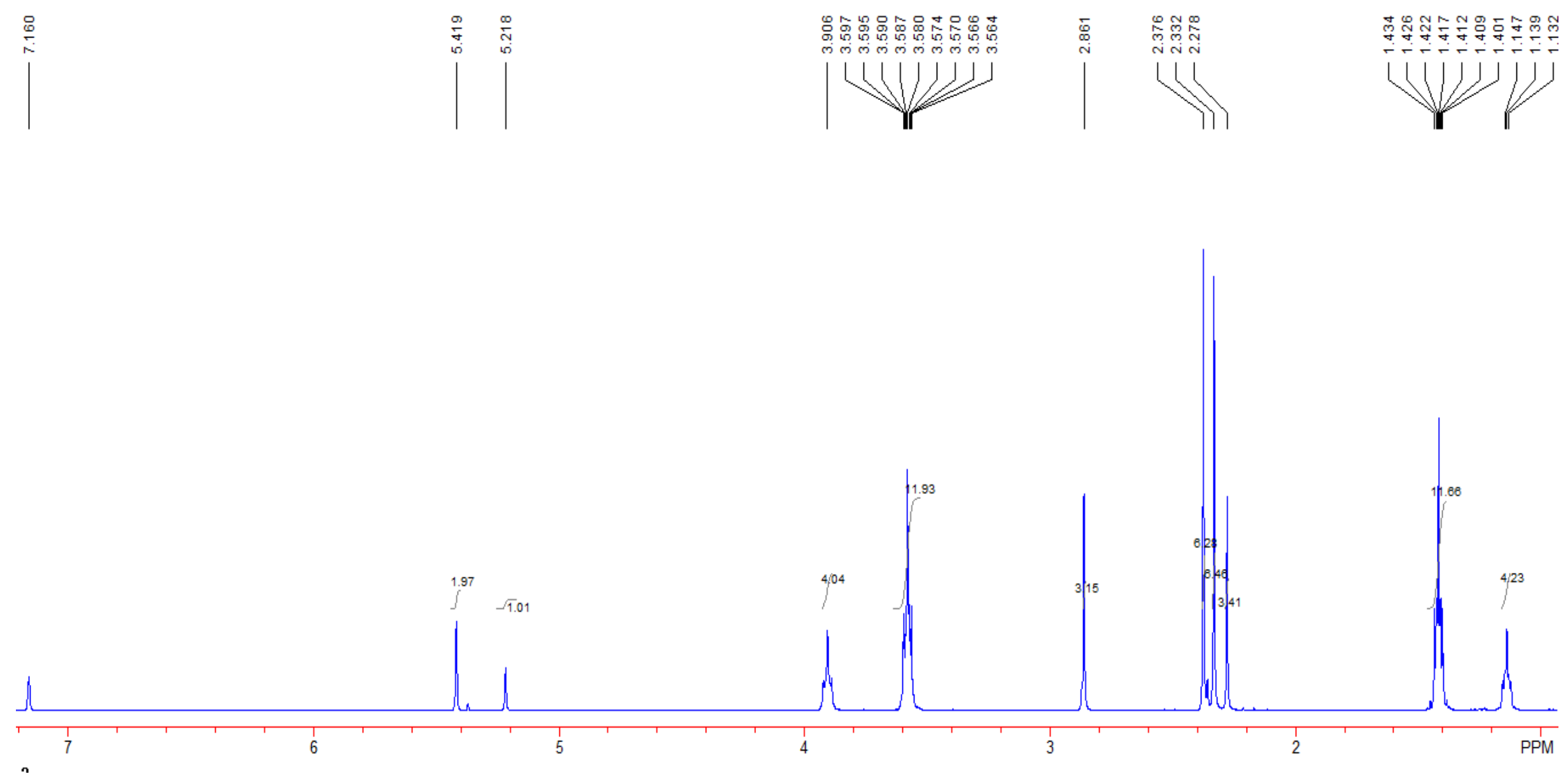

Figure S4. ${ }^{1} \mathrm{H}$ NMR spectrum of complex $1\left(400 \mathrm{MHz}, \mathrm{C}_{6} \mathrm{D}_{6}, 25{ }^{\circ} \mathrm{C}\right)$. 


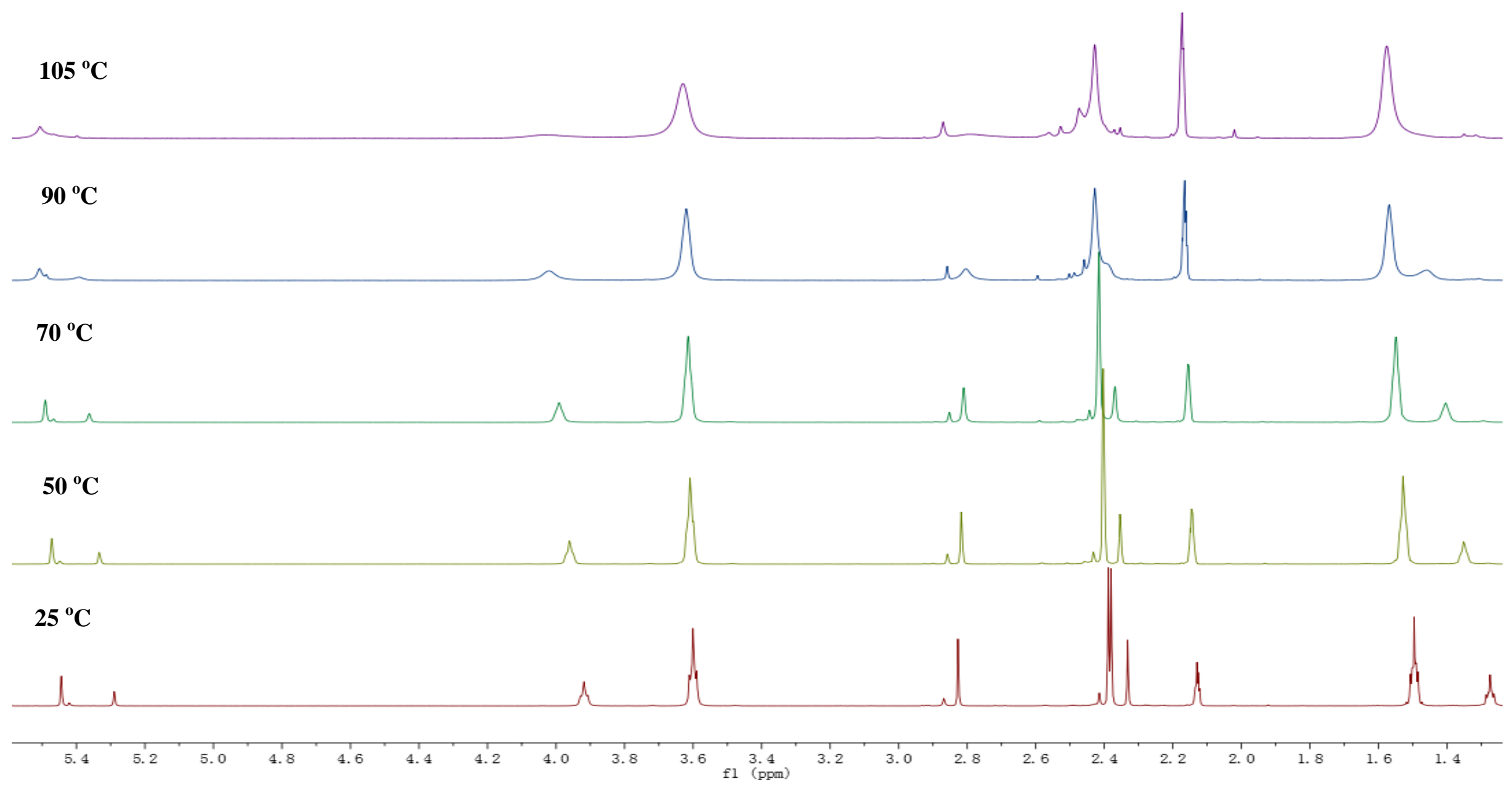

Figure S5. Variable-temperature ${ }^{1} \mathrm{H}$ NMR spectra of 1 in toluene- $d_{8}(600 \mathrm{MHz})$. 


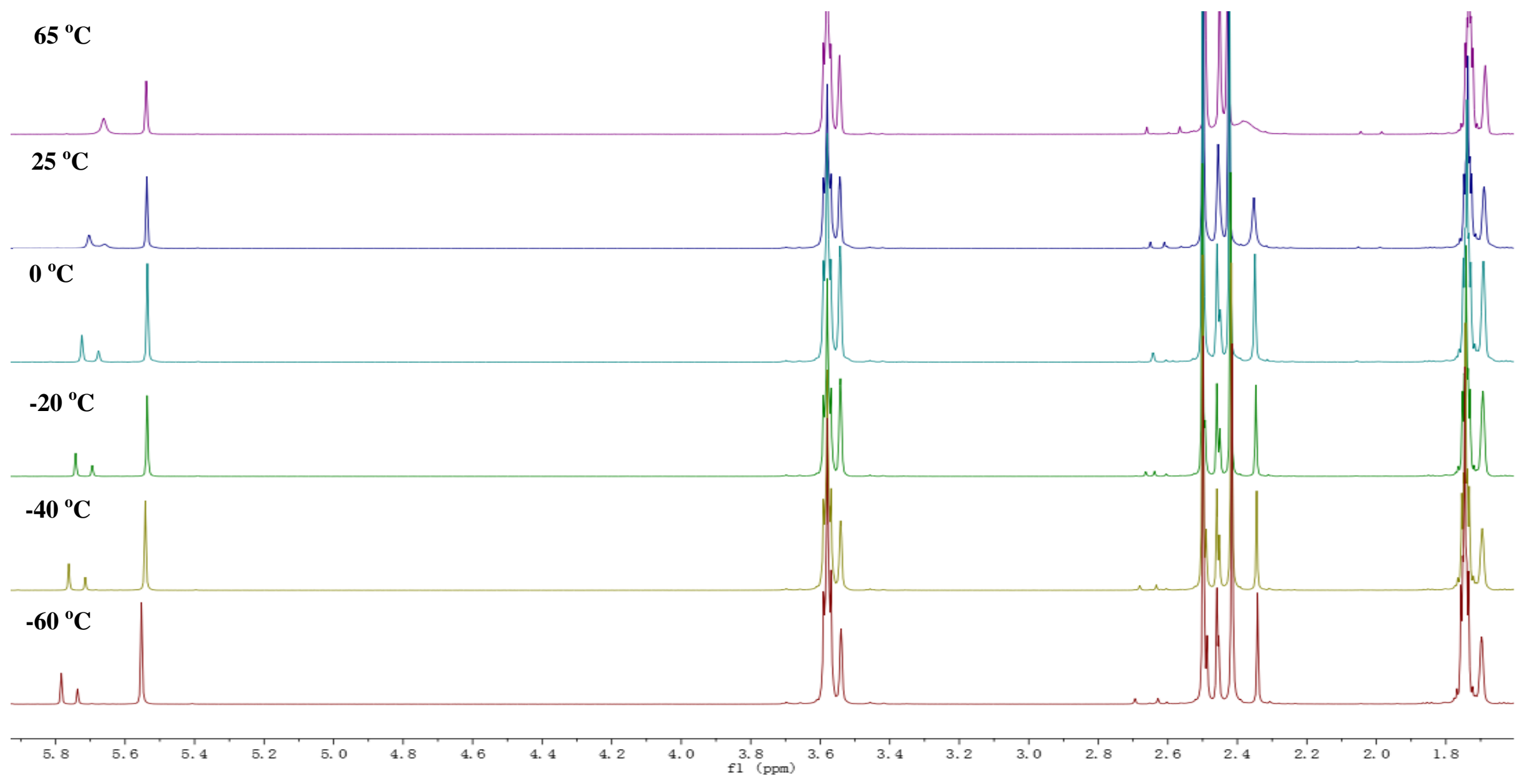

Figure S6. Variable-temperature ${ }^{1} \mathrm{H}$ NMR spectra of 1 inTHF- $d_{8}(600 \mathrm{MHz})$.

S8 


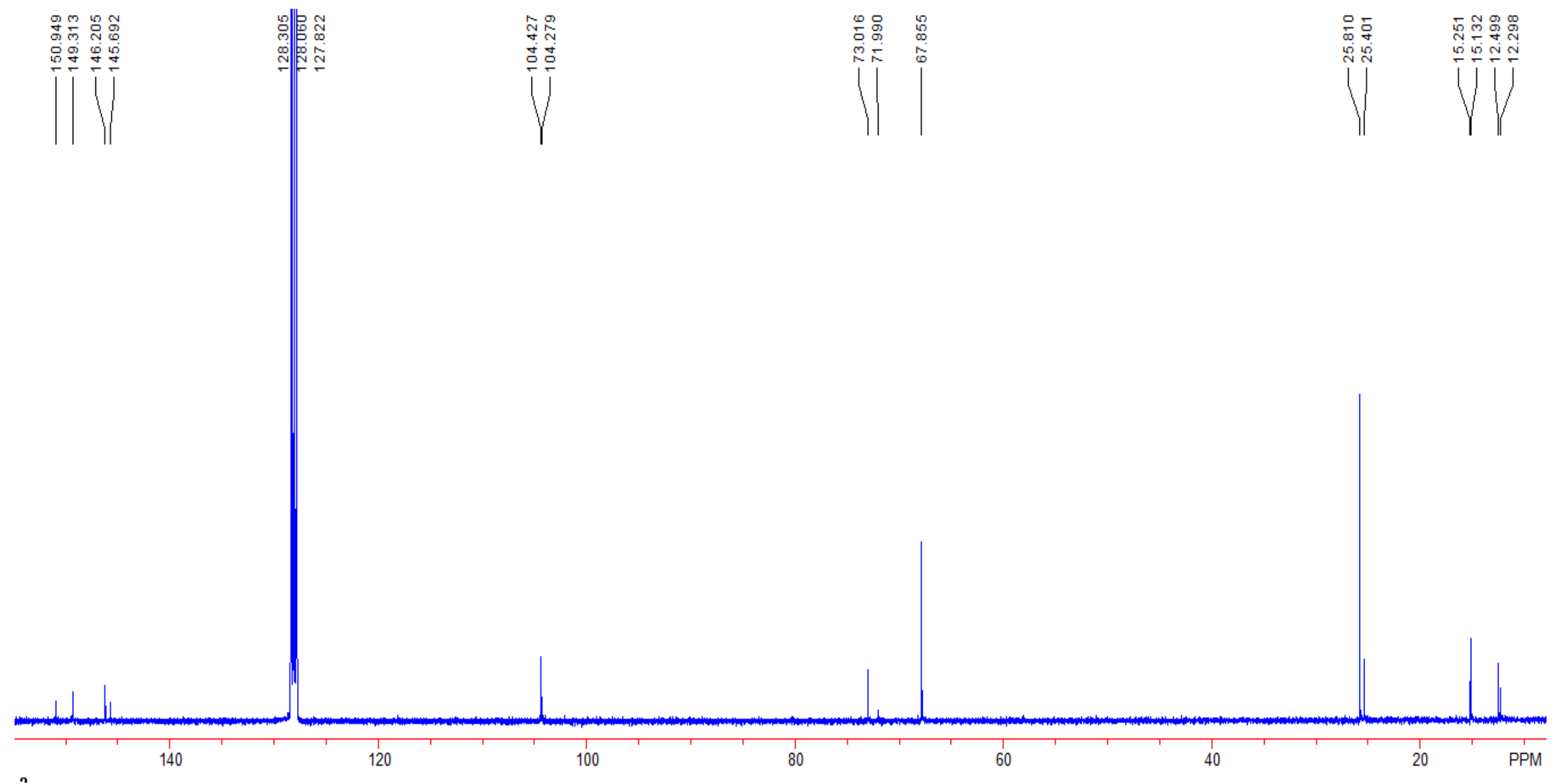

Figure S7. ${ }^{13} \mathrm{C}$ NMR spectrum of complex $1\left(100 \mathrm{MHz}, \mathrm{C}_{6} \mathrm{D}_{6}, 25^{\circ} \mathrm{C}\right)$. 


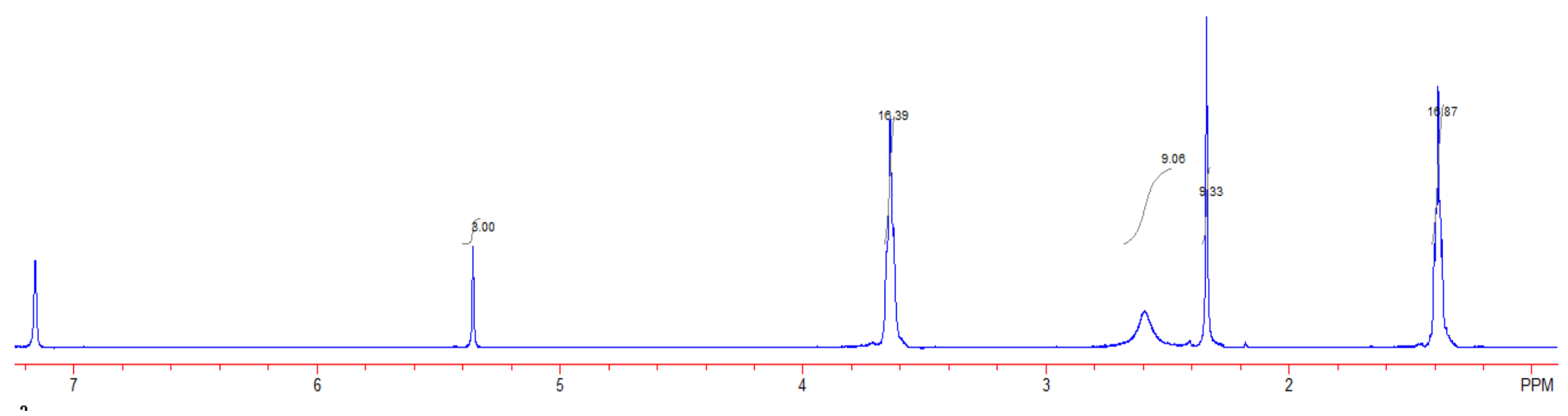

Figure S8. ${ }^{1} \mathrm{H}$ NMR spectrum of complex $2\left(400 \mathrm{MHz}, \mathrm{C}_{6} \mathrm{D}_{6}, 25{ }^{\circ} \mathrm{C}\right)$. 


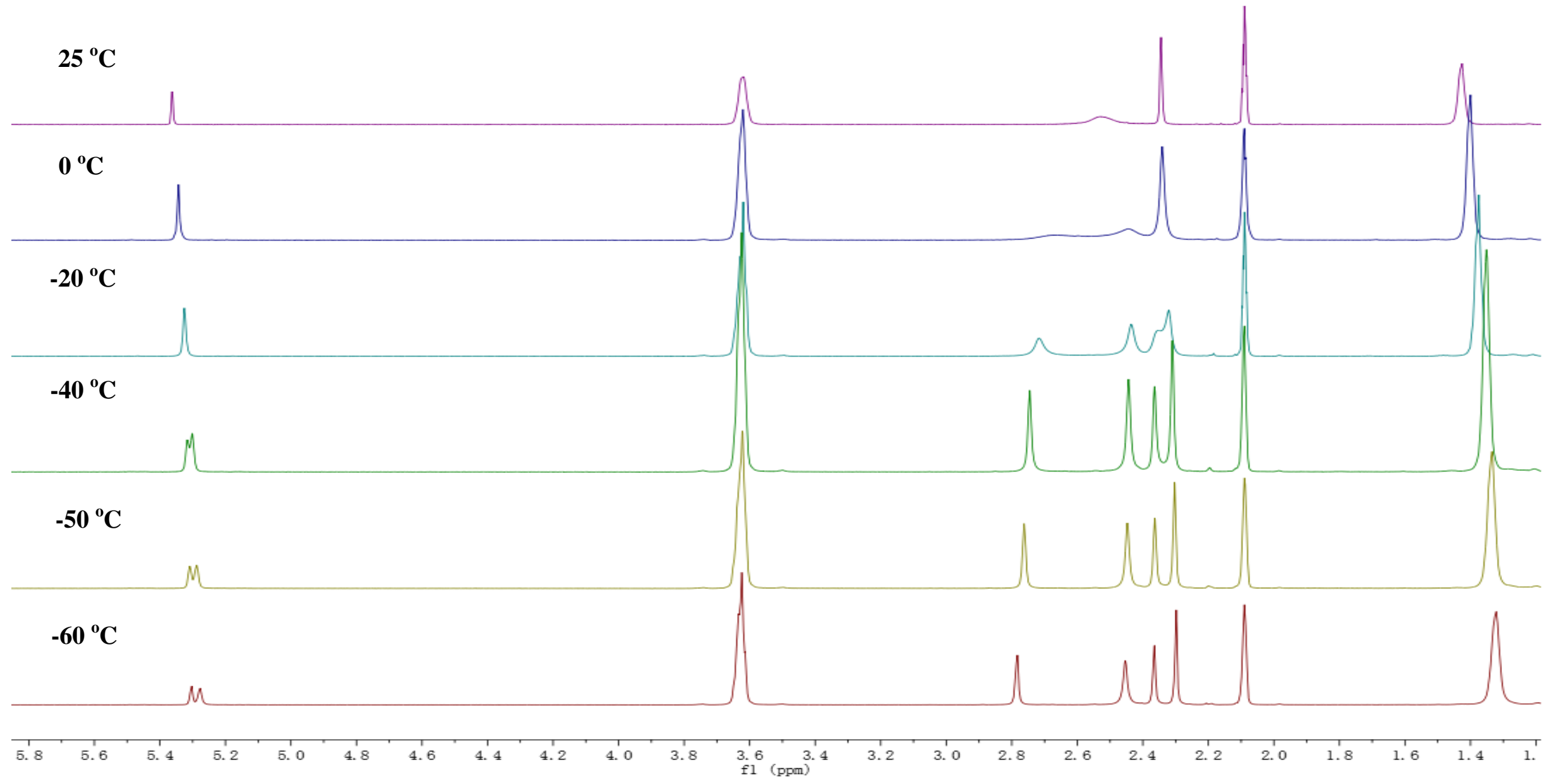

Figure S9. Variable-temperature ${ }^{1} \mathrm{H}$ NMR spectra of 2 in toluene- $d_{8}(600 \mathrm{MHz})$. 


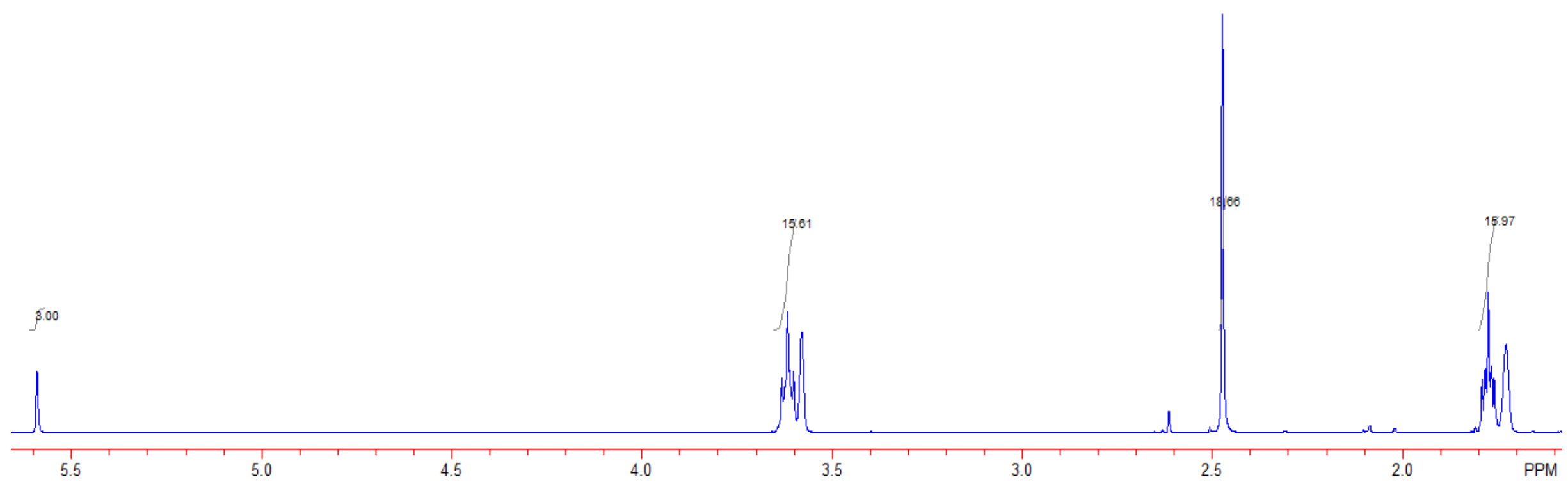

Figure S10. ${ }^{1} \mathrm{H}$ NMR spectrum of complex $2\left(400 \mathrm{MHz}, \mathrm{THF}-d_{8}, 25{ }^{\circ} \mathrm{C}\right)$. 

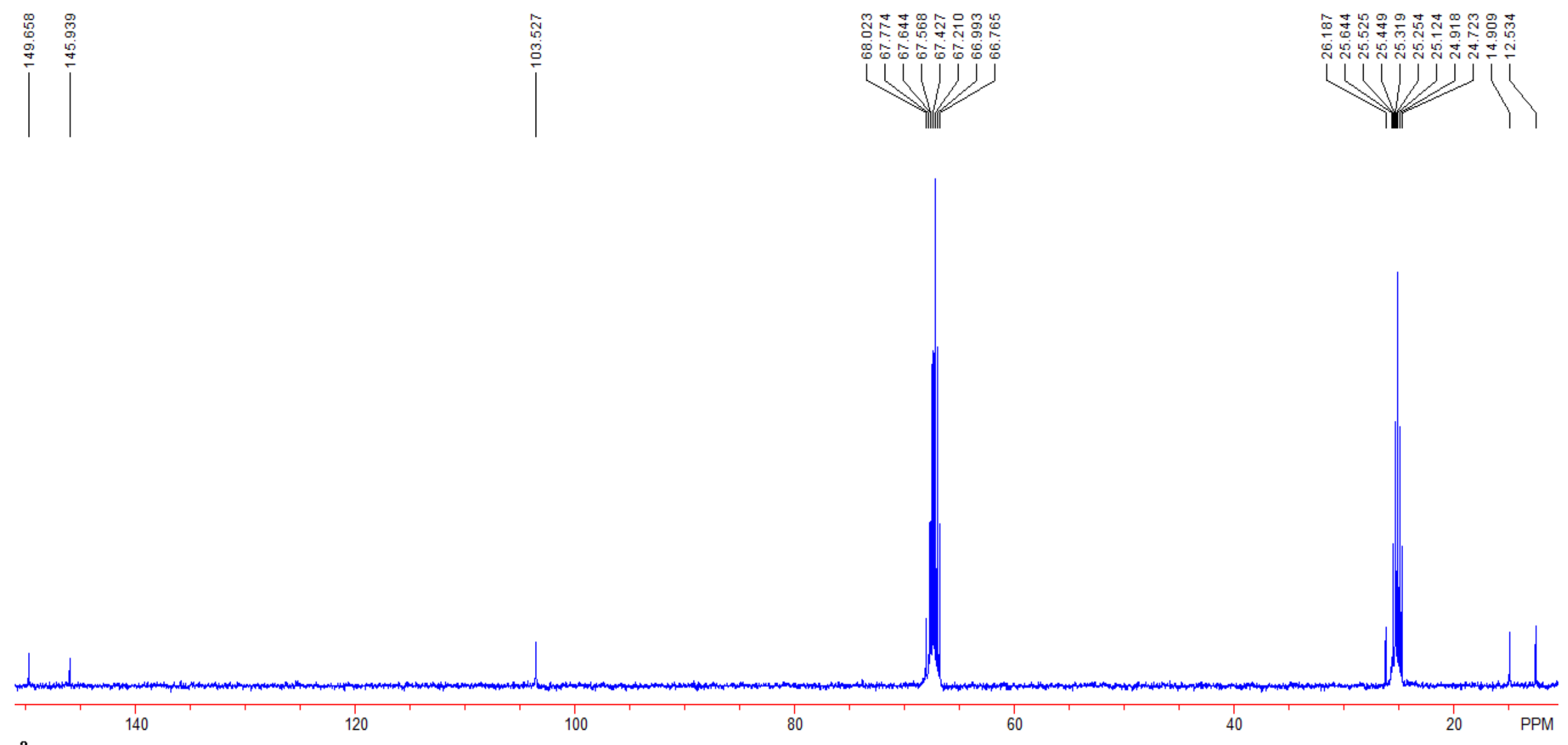

Figure S11. ${ }^{13} \mathrm{C}$ NMR spectrum of complex $2\left(100 \mathrm{MHz}, \mathrm{THF}-d_{8}, 25{ }^{\circ} \mathrm{C}\right)$. 

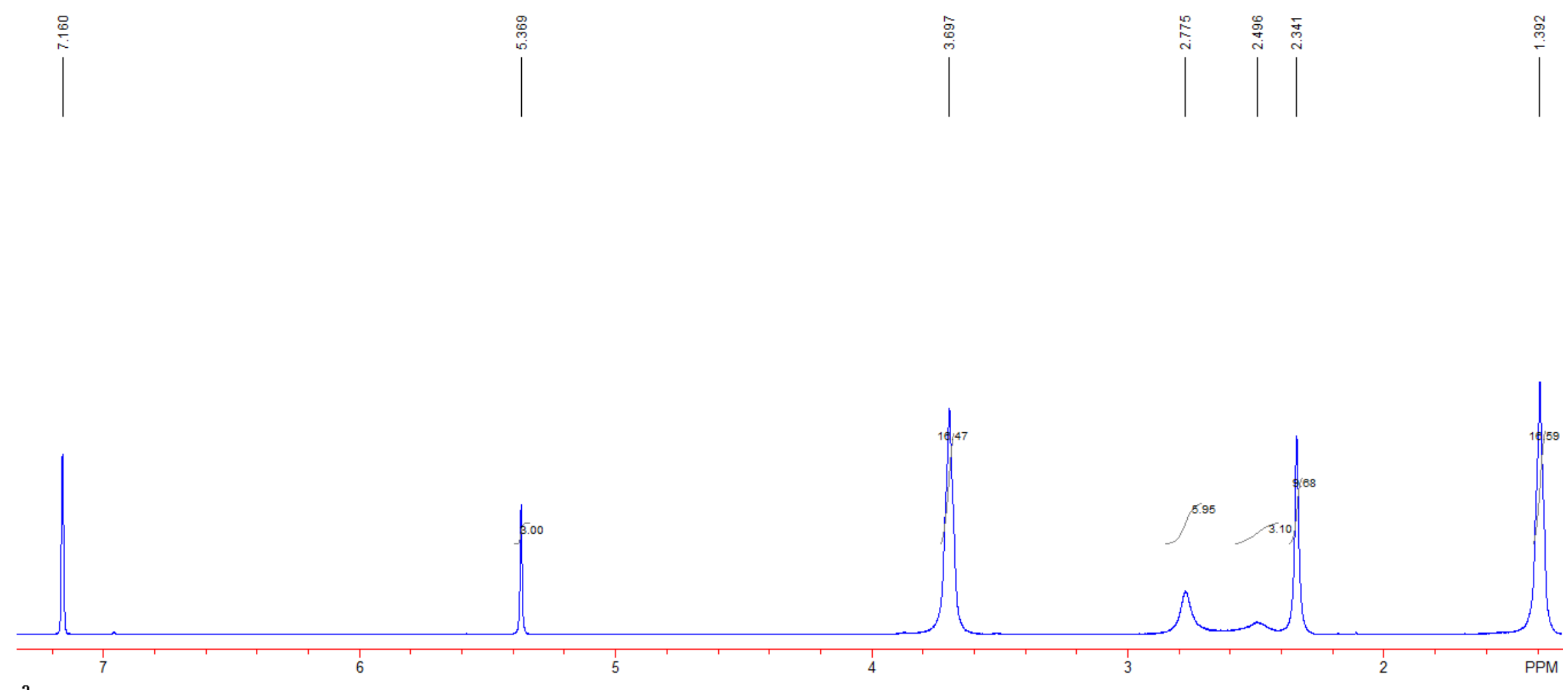

Figure S12. ${ }^{1} \mathrm{H}$ NMR spectrum of complex $3\left(400 \mathrm{MHz}, \mathrm{C}_{6} \mathrm{D}_{6}, 25{ }^{\circ} \mathrm{C}\right)$. 


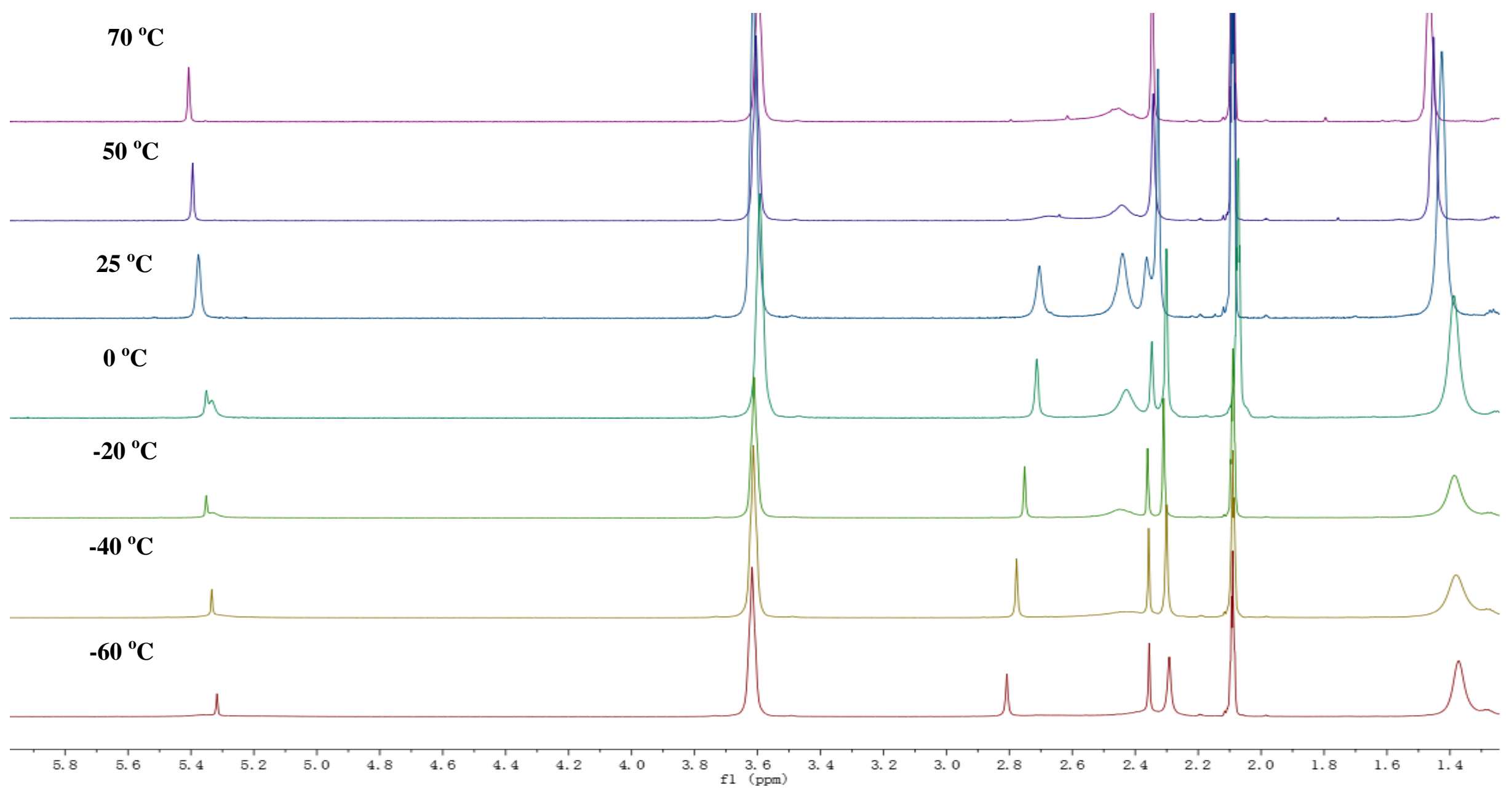

Figure S13. Variable-temperature ${ }^{1} \mathrm{H}$ NMR spectra of 3 in toluene- $d_{8}(600 \mathrm{MHz})$. 

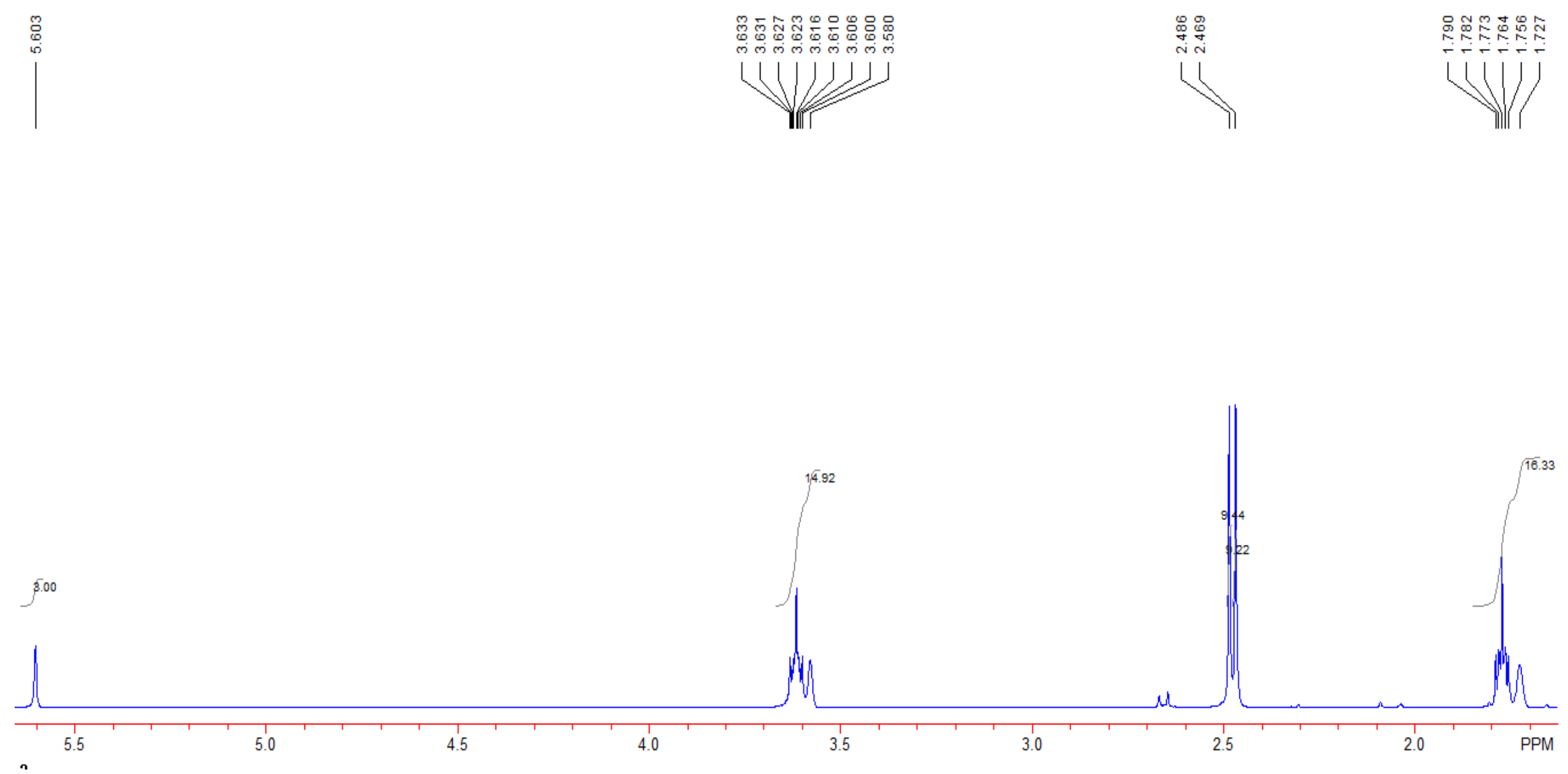

Figure S14. ${ }^{1} \mathrm{H}$ NMR spectrum of complex $3\left(400 \mathrm{MHz}, \mathrm{THF}-d_{8}, 25{ }^{\circ} \mathrm{C}\right)$. 


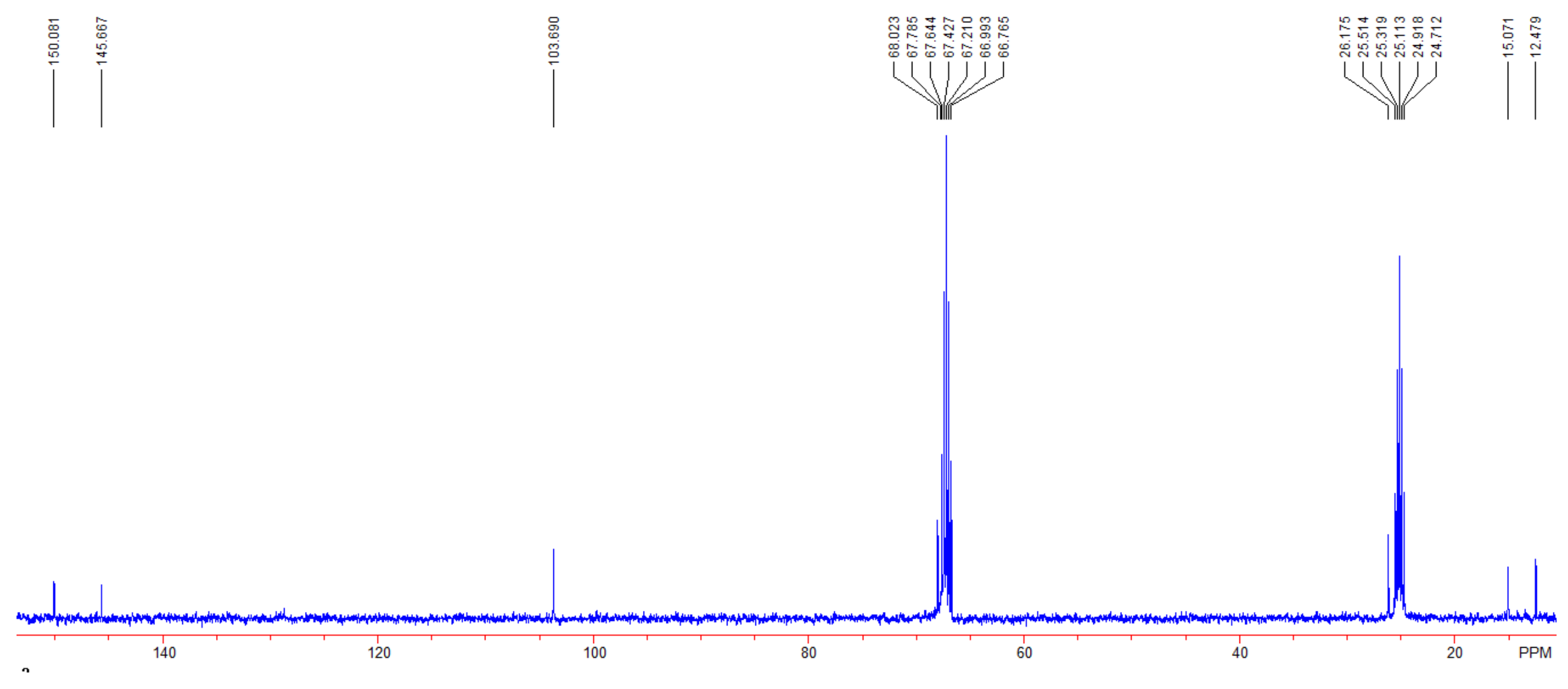

Figure S15. ${ }^{13} \mathrm{C}$ NMR spectrum of complex $3\left(100 \mathrm{MHz}, \mathrm{THF}-d_{8}, 25{ }^{\circ} \mathrm{C}\right)$. 


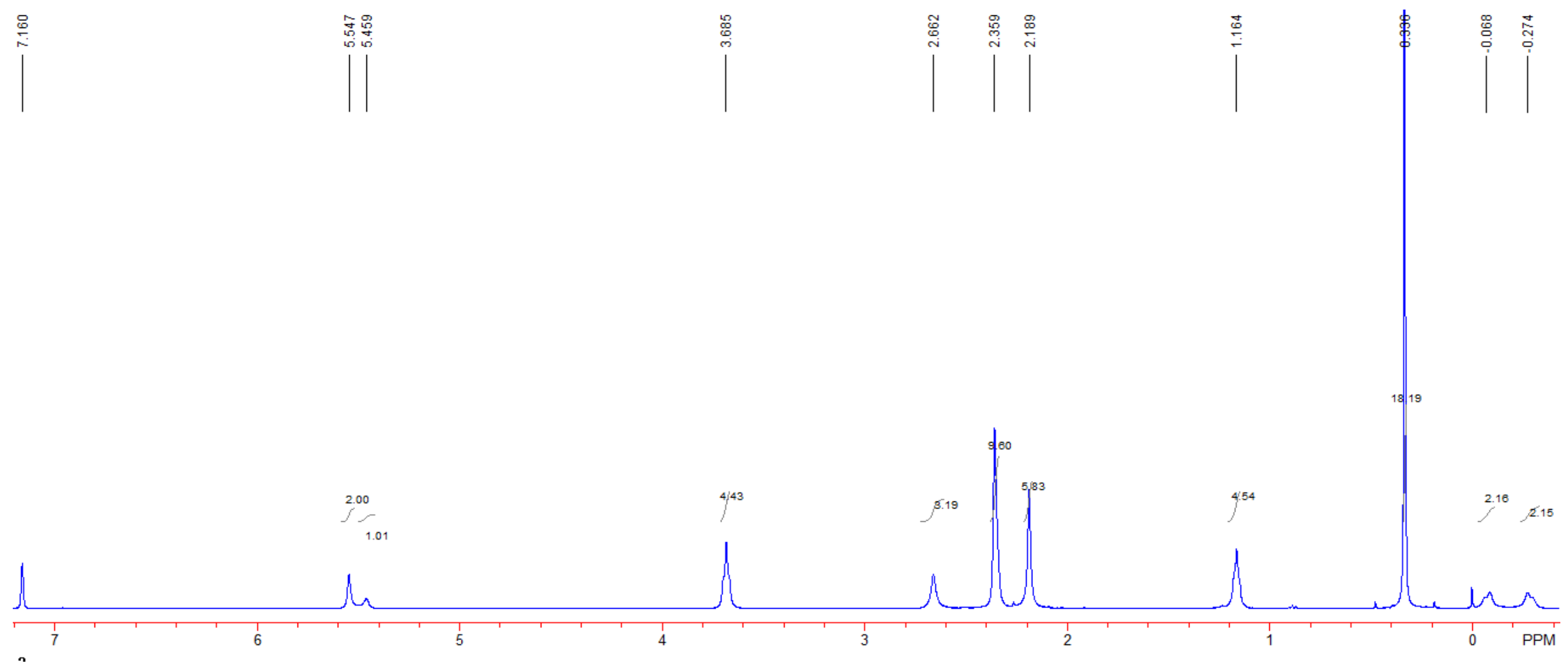

Figure S16. ${ }^{1} \mathrm{H}$ NMR spectrum of complex $4\left(400 \mathrm{MHz}, \mathrm{C}_{6} \mathrm{D}_{6}, 25{ }^{\circ} \mathrm{C}\right)$. 


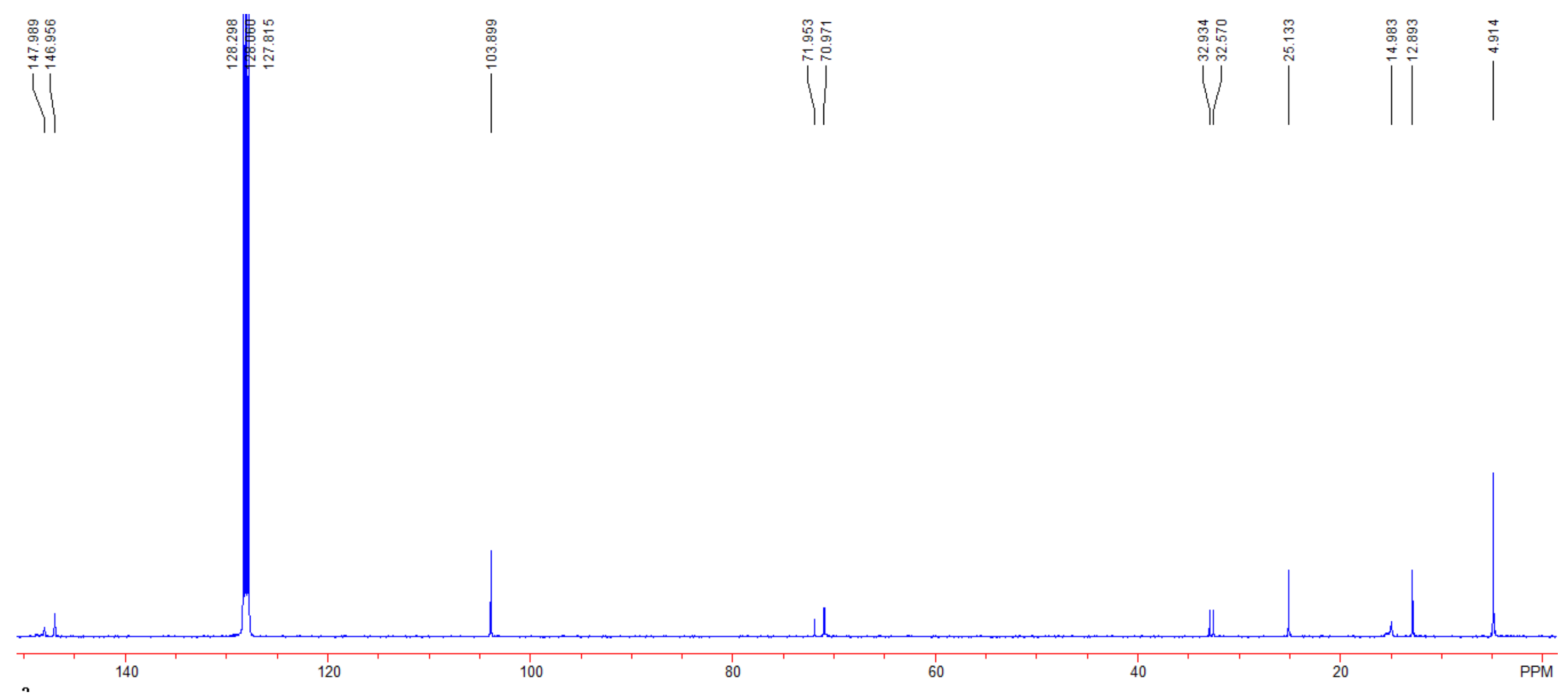

Figure S17. ${ }^{13} \mathrm{C}$ NMR spectrum of complex $4\left(100 \mathrm{MHz}, \mathrm{C}_{6} \mathrm{D}_{6}, 25{ }^{\circ} \mathrm{C}\right)$. 


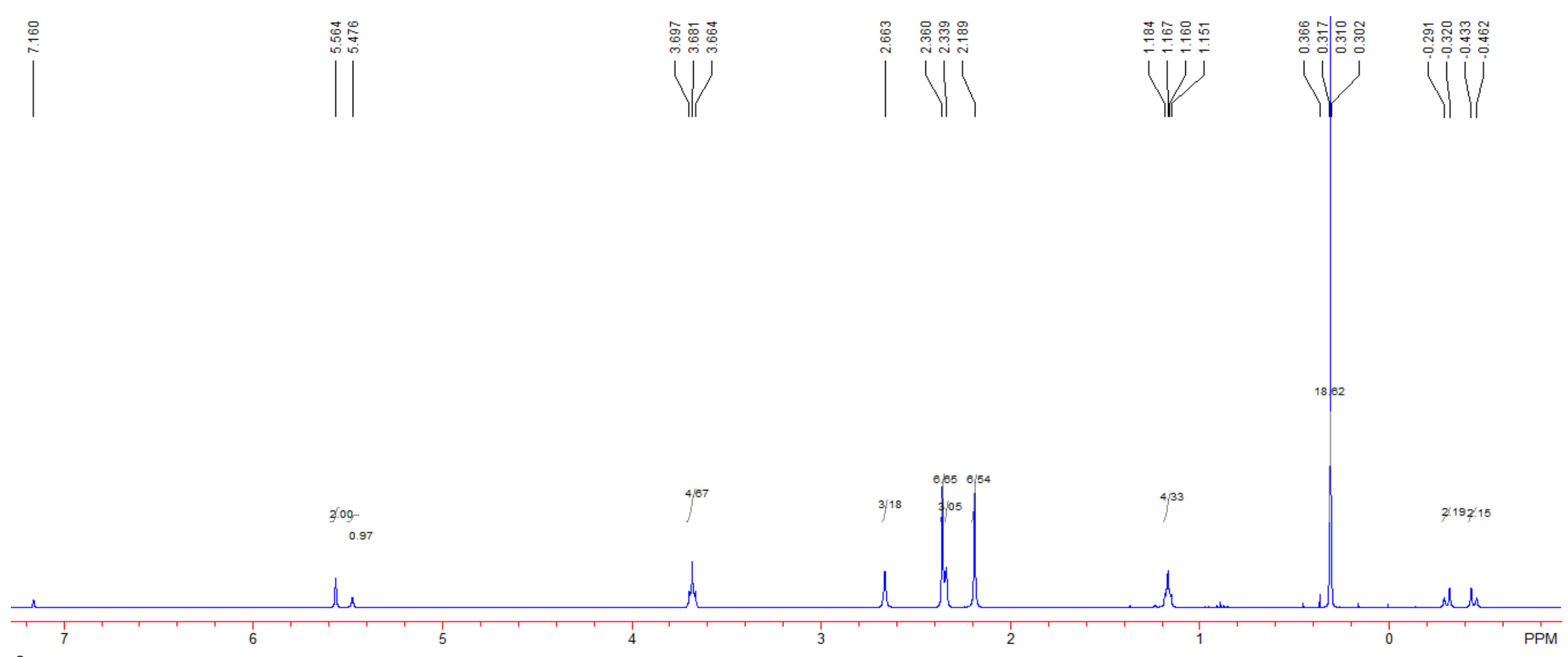

Figure S18. ${ }^{1} \mathrm{H}$ NMR spectrum of complex $5\left(400 \mathrm{MHz}, \mathrm{C}_{6} \mathrm{D}_{6}, 25{ }^{\circ} \mathrm{C}\right)$. 


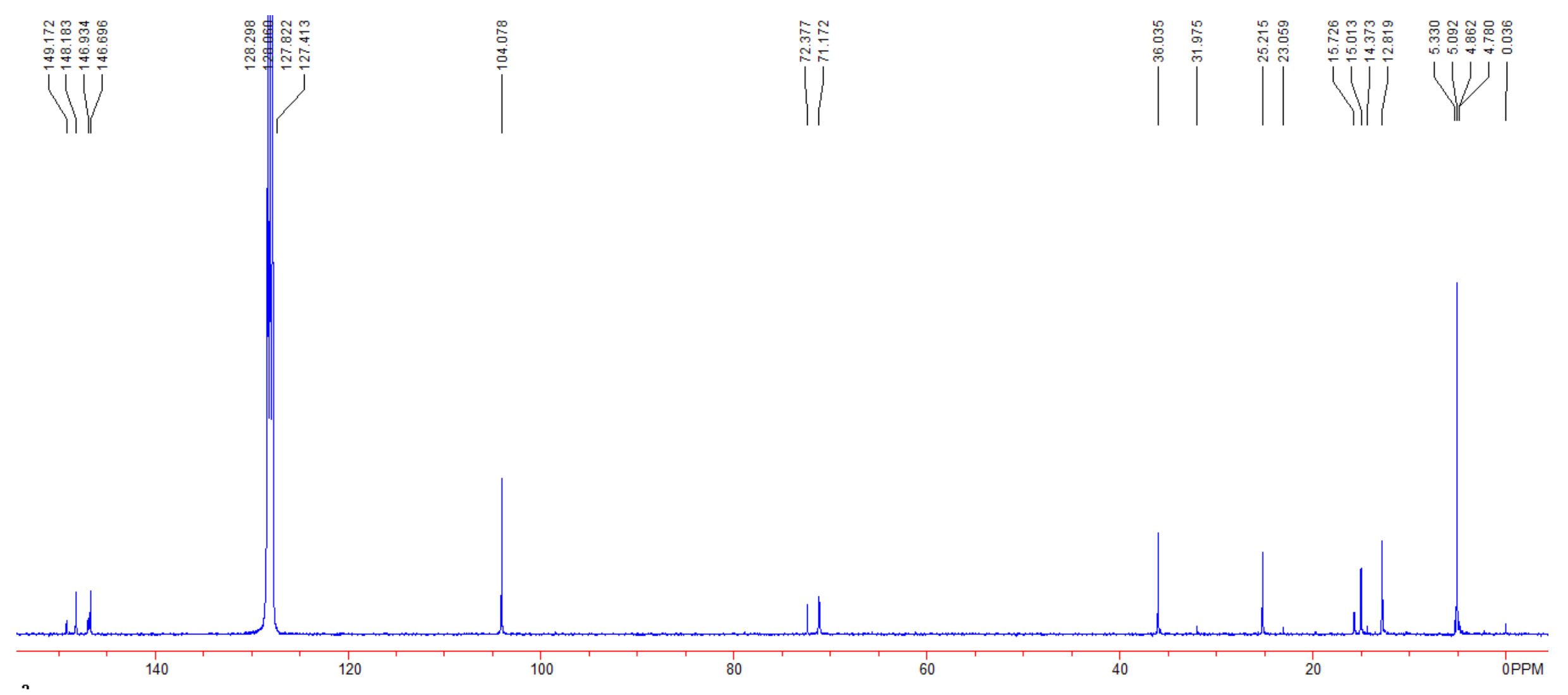

Figure S19. ${ }^{13} \mathrm{C}$ NMR spectrum of complex $5\left(100 \mathrm{MHz}, \mathrm{C}_{6} \mathrm{D}_{6}, 25{ }^{\circ} \mathrm{C}\right)$. 

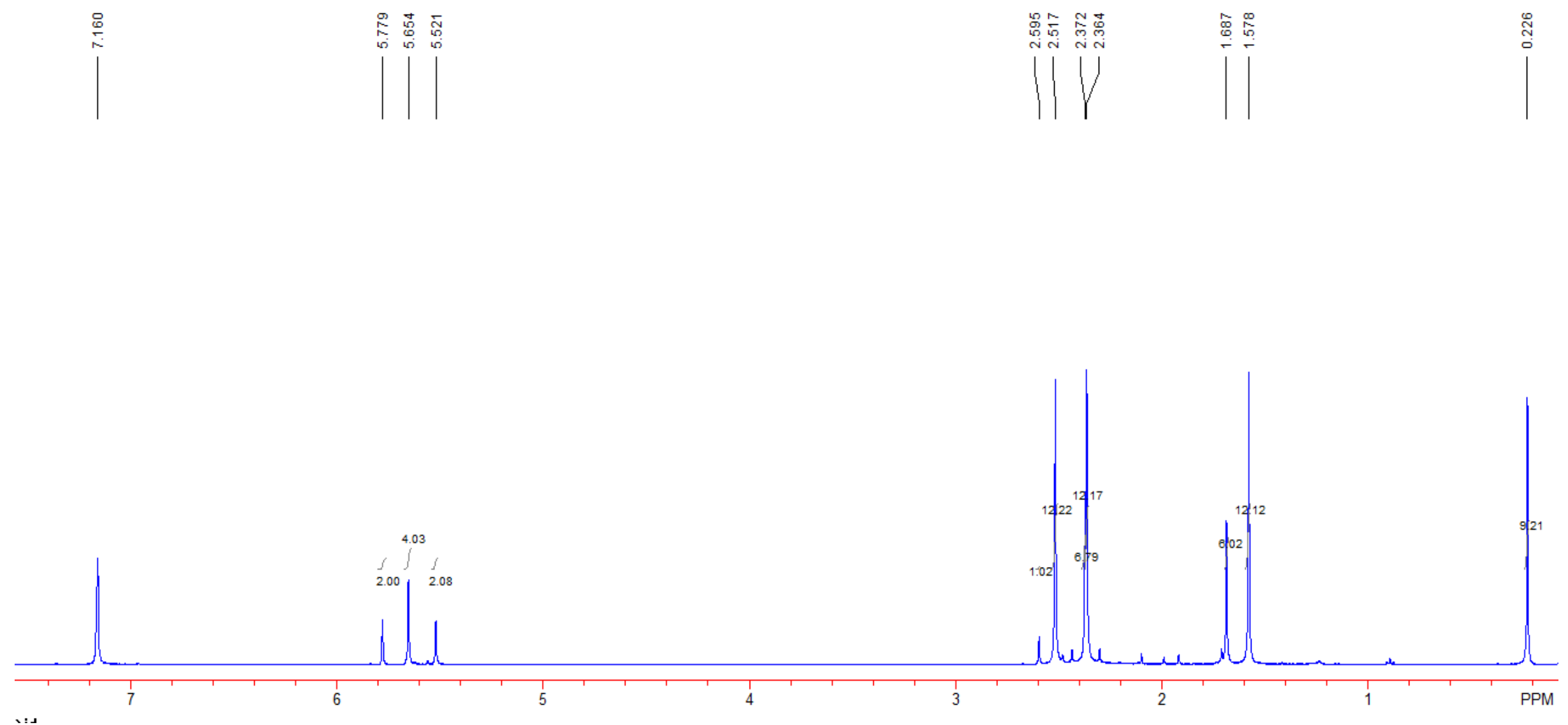

Figure S20. ${ }^{1} \mathrm{H}$ NMR spectrum of complex $6\left(400 \mathrm{MHz}, \mathrm{C}_{6} \mathrm{D}_{6}, 25{ }^{\circ} \mathrm{C}\right)$. 


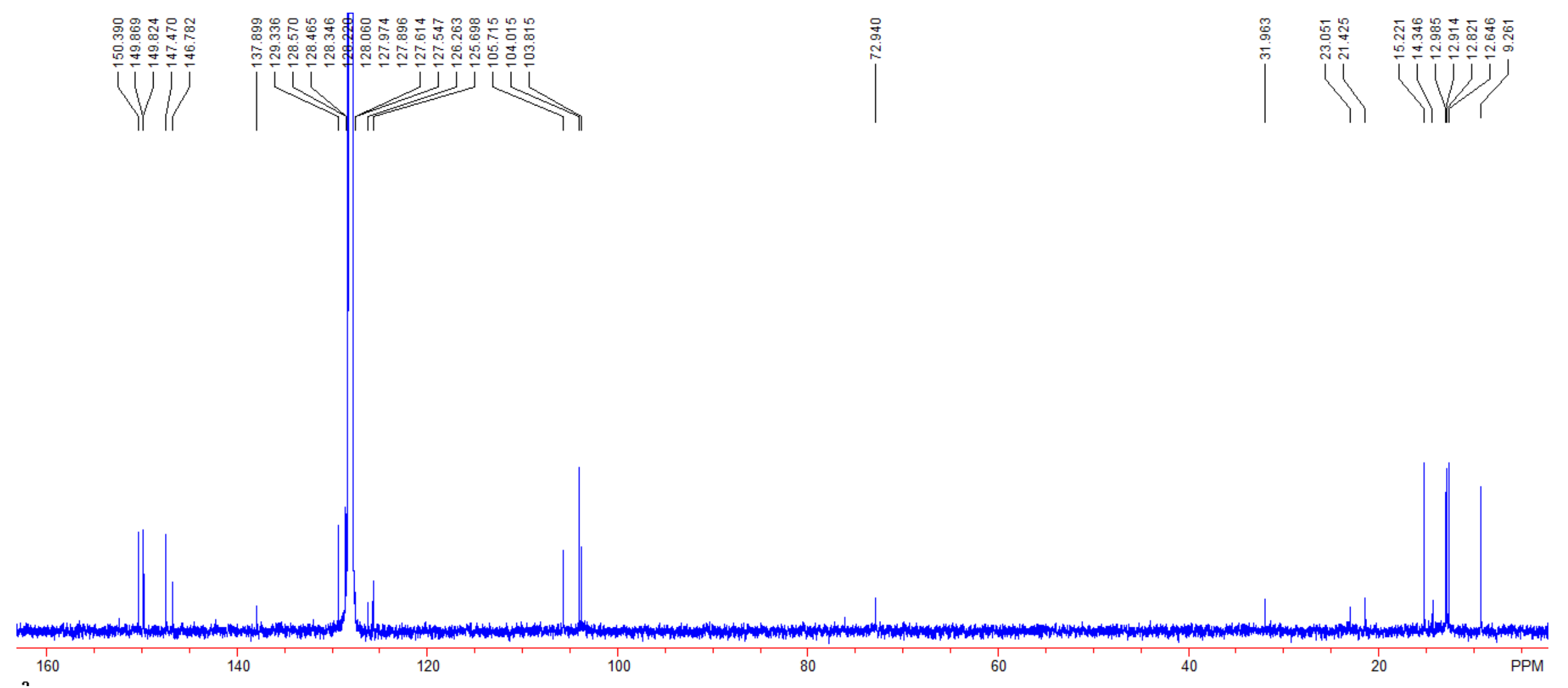

Figure S21. ${ }^{1} \mathrm{H}$ NMR spectrum of complex $6\left(150 \mathrm{MHz}, \mathrm{C}_{6} \mathrm{D}_{6}, 25{ }^{\circ} \mathrm{C}\right)$. 

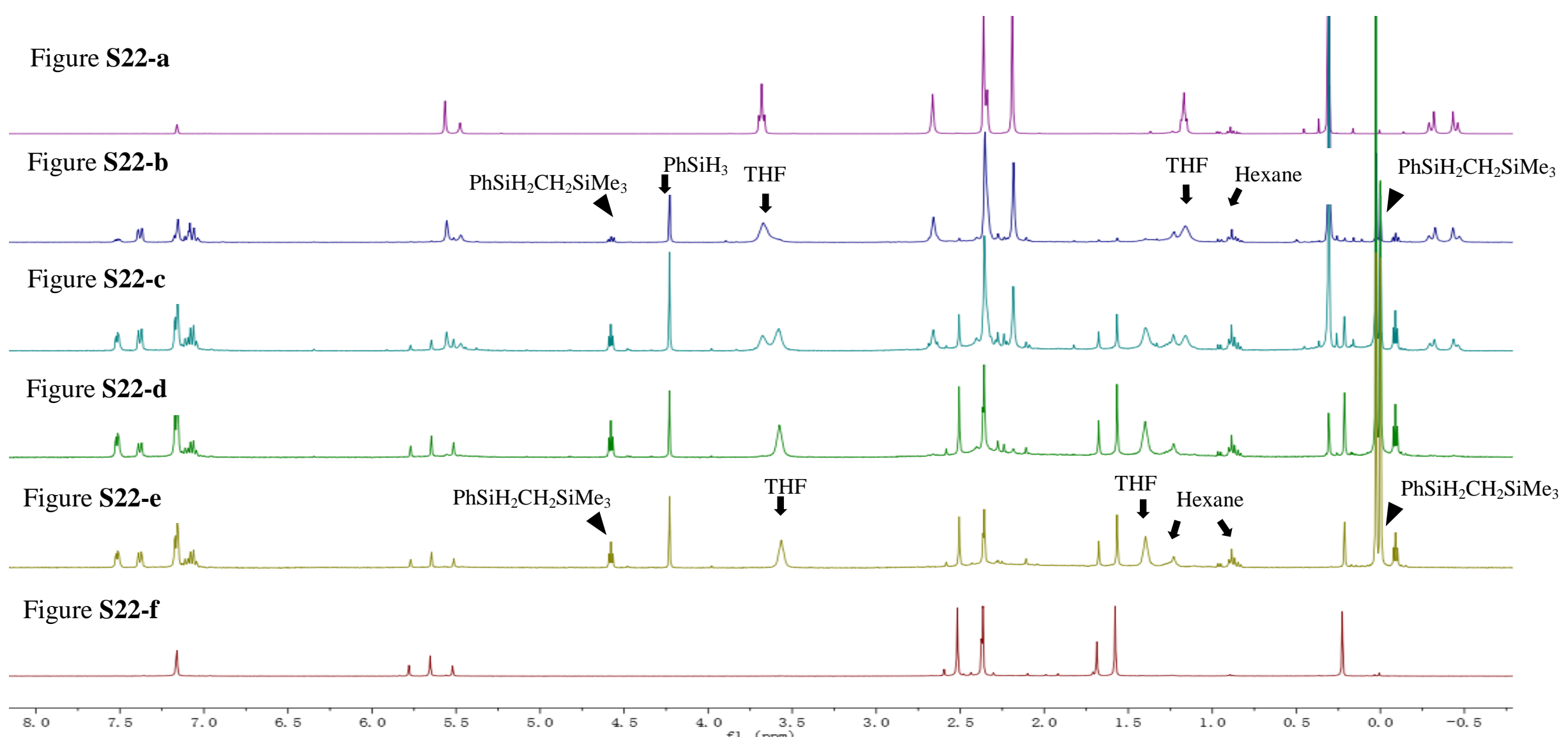

Figure S22. ${ }^{1} \mathrm{H}$ NMR spectral monitoring of the reaction of 5 with 2 equiv. of $\mathrm{PhSiH}_{3}\left(400 \mathrm{MHz}, \mathrm{C}_{6} \mathrm{D}_{6}, 25{ }^{\circ} \mathrm{C}\right)$. a) ${ }^{1} \mathrm{H} \mathrm{NMR}$ spectrum of $\mathbf{5}$; b) ${ }^{1} \mathrm{H}$ NMR spectrum of the reaction solution of $\mathbf{5}$ with $\mathrm{PhSiH}_{3}$ after 6 hours at room temperature; c) ${ }^{1} \mathrm{H}$ NMR spectrum of the reaction solution of $\mathbf{5}$ with $\mathrm{PhSiH}_{3}$ after 5 hours at $50{ }^{\circ} \mathrm{C}$; d) ${ }^{1} \mathrm{H}$ NMR spectrum of the reaction solution of 5 with $\mathrm{PhSiH}_{3}$ after 18 hours at $50{ }^{\circ} \mathrm{C}$; e) ${ }^{1} \mathrm{H} \mathrm{NMR}$ spectrum of the reaction solution of 5 with $\mathrm{PhSiH}_{3}$ after 3 hours at $75^{\circ} \mathrm{C}$; f) ${ }^{1} \mathrm{H}$ NMR spectrum of $\mathbf{6}$. The resonances of hexane are due to the residue of hexane in $\mathrm{C}_{6} \mathrm{D}_{6}$. 


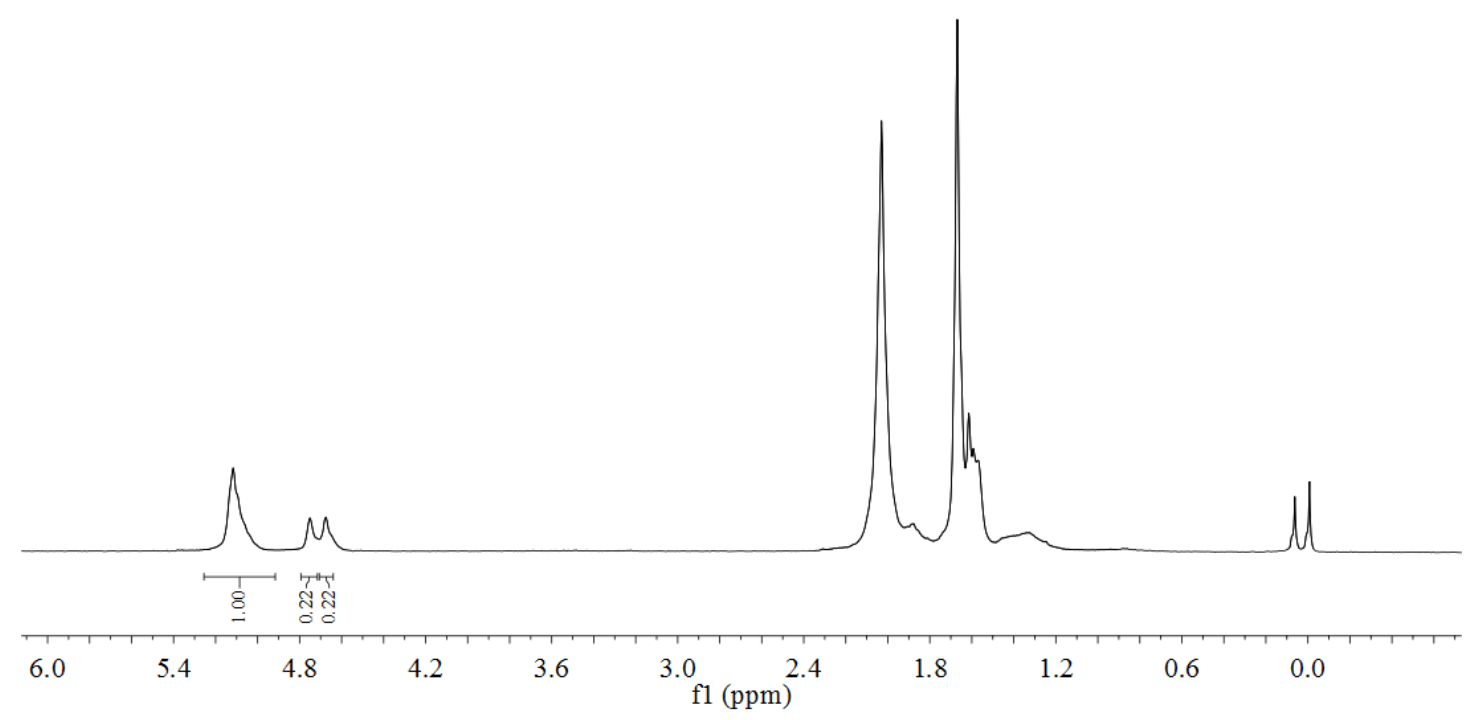

Figure S23. ${ }^{1} \mathrm{H}$ NMR spectrum of polyisoprene for the entry 3 in Table 1.

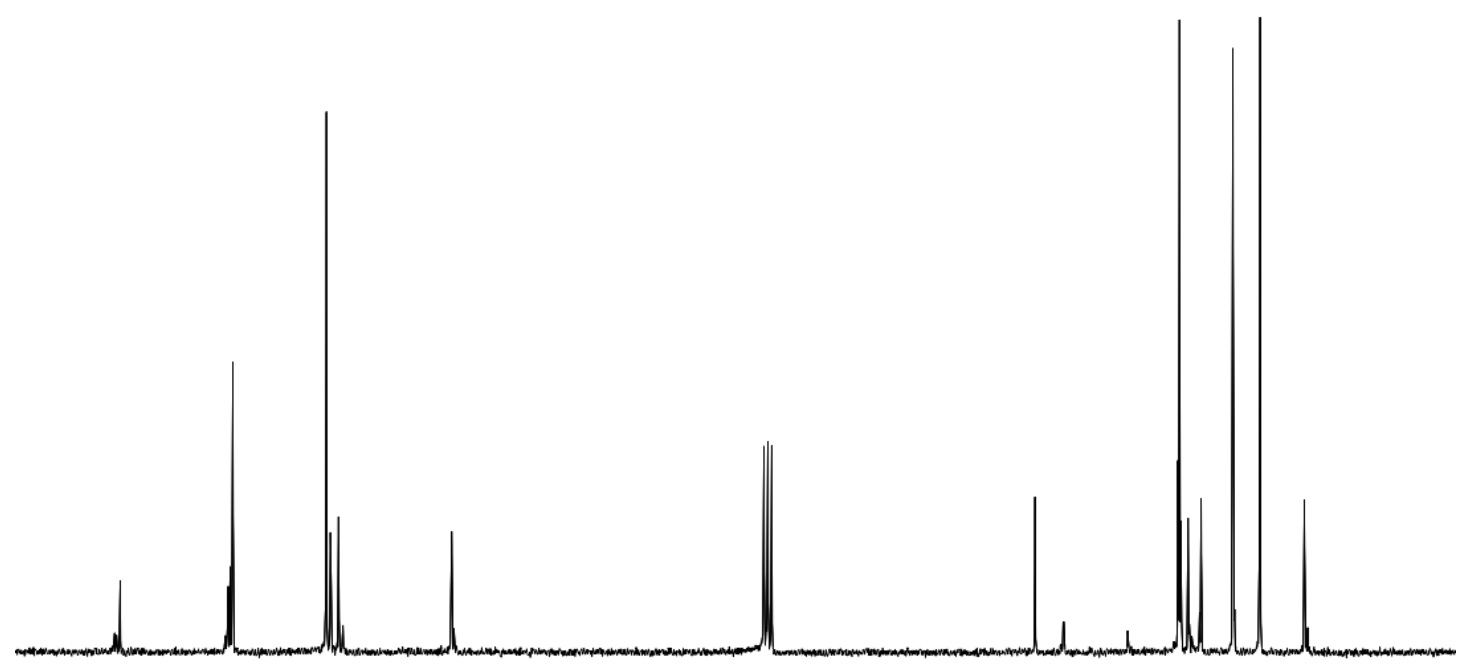

$\begin{array}{lllllllllllllll}150 & 140 & 130 & 120 & 110 & 100 & 90 & \underset{\mathrm{f} 1(\mathrm{ppm})}{80} & 70 & 60 & 50 & 40 & 30 & 20 & 10\end{array}$

Figure S24. ${ }^{13} \mathrm{C}$ NMR spectrum of polyisoprene for the entry 3 in Table 1 (scan 8000 times). No 1,4-trans-polymer was observed. 


$$
\bar{i} \stackrel{\infty}{i} \dot{i} i
$$

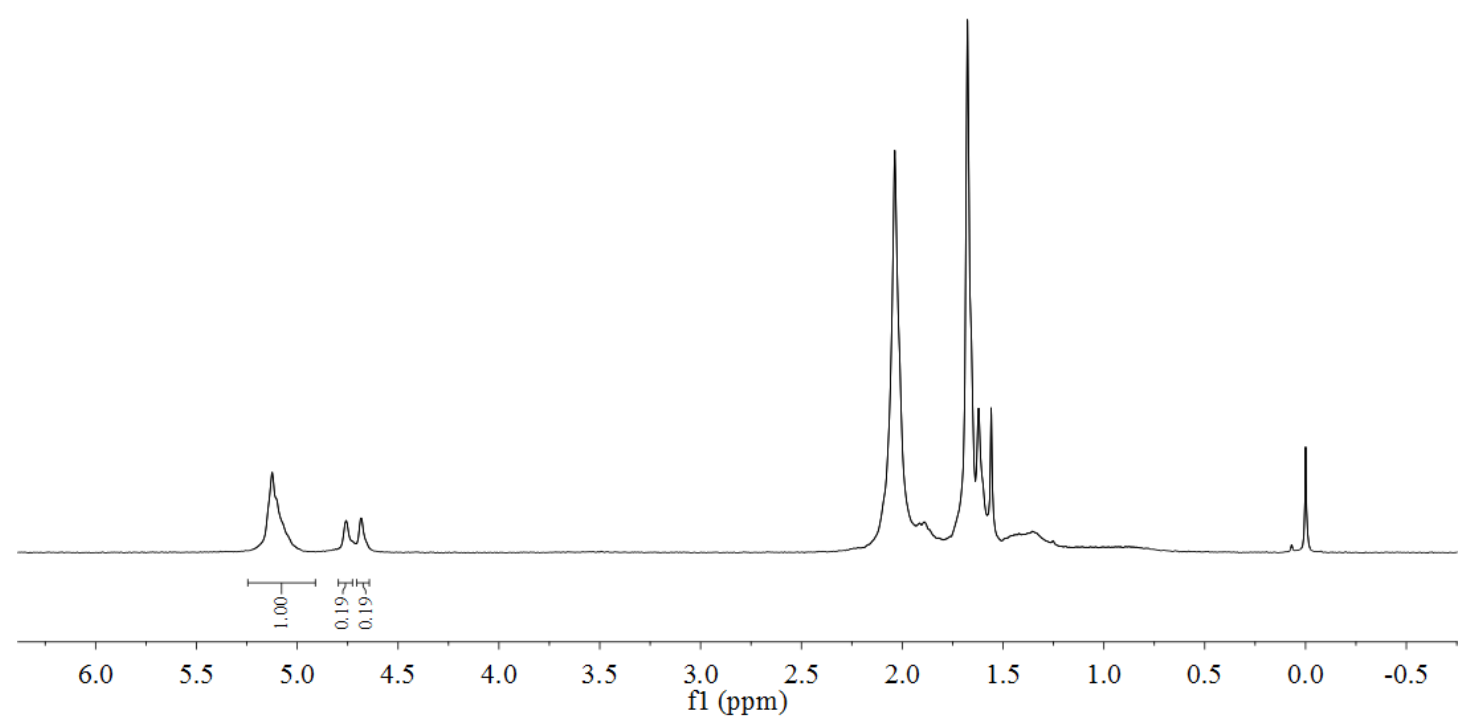

Figure S25. ${ }^{1} \mathrm{H}$ NMR spectrum of polyisoprene for the entry 5 in Table 1.

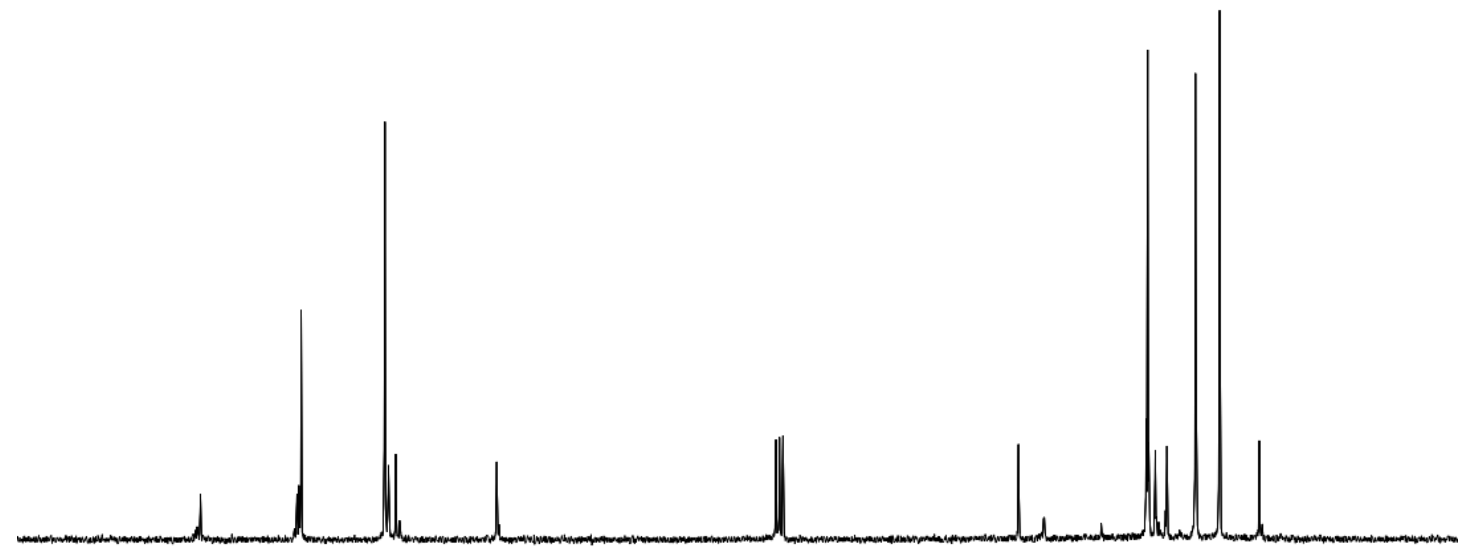

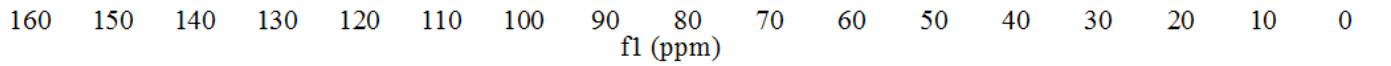

Figure S26. ${ }^{13} \mathrm{C}$ NMR spectrum of polyisoprene for the entry 5 in Table 1 (scan 8000 times). No 1,4-trans-polymer was observed. 


$$
\bar{i} \stackrel{\infty}{i} \dot{i}
$$

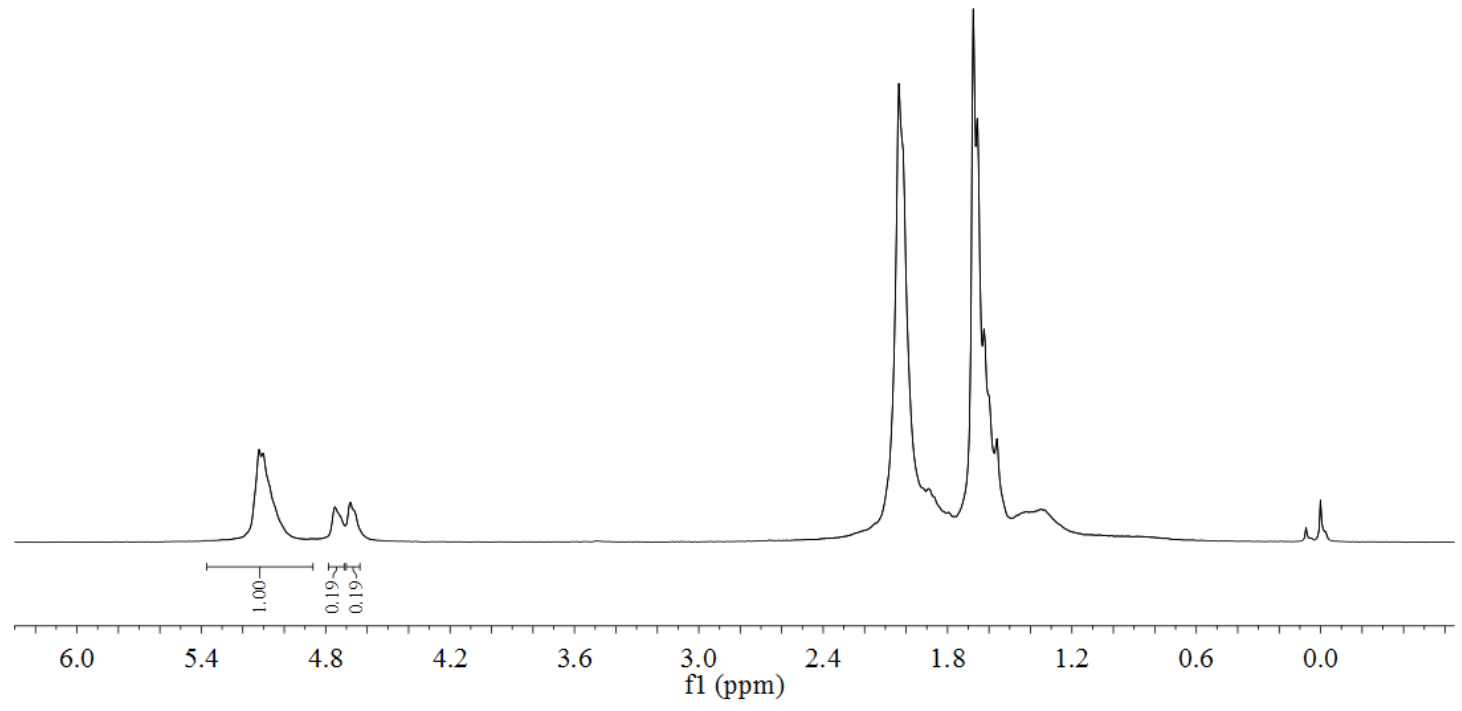

Figure S27. ${ }^{1} \mathrm{H}$ NMR spectrum of polyisoprene for the entry 6 in Table 1.
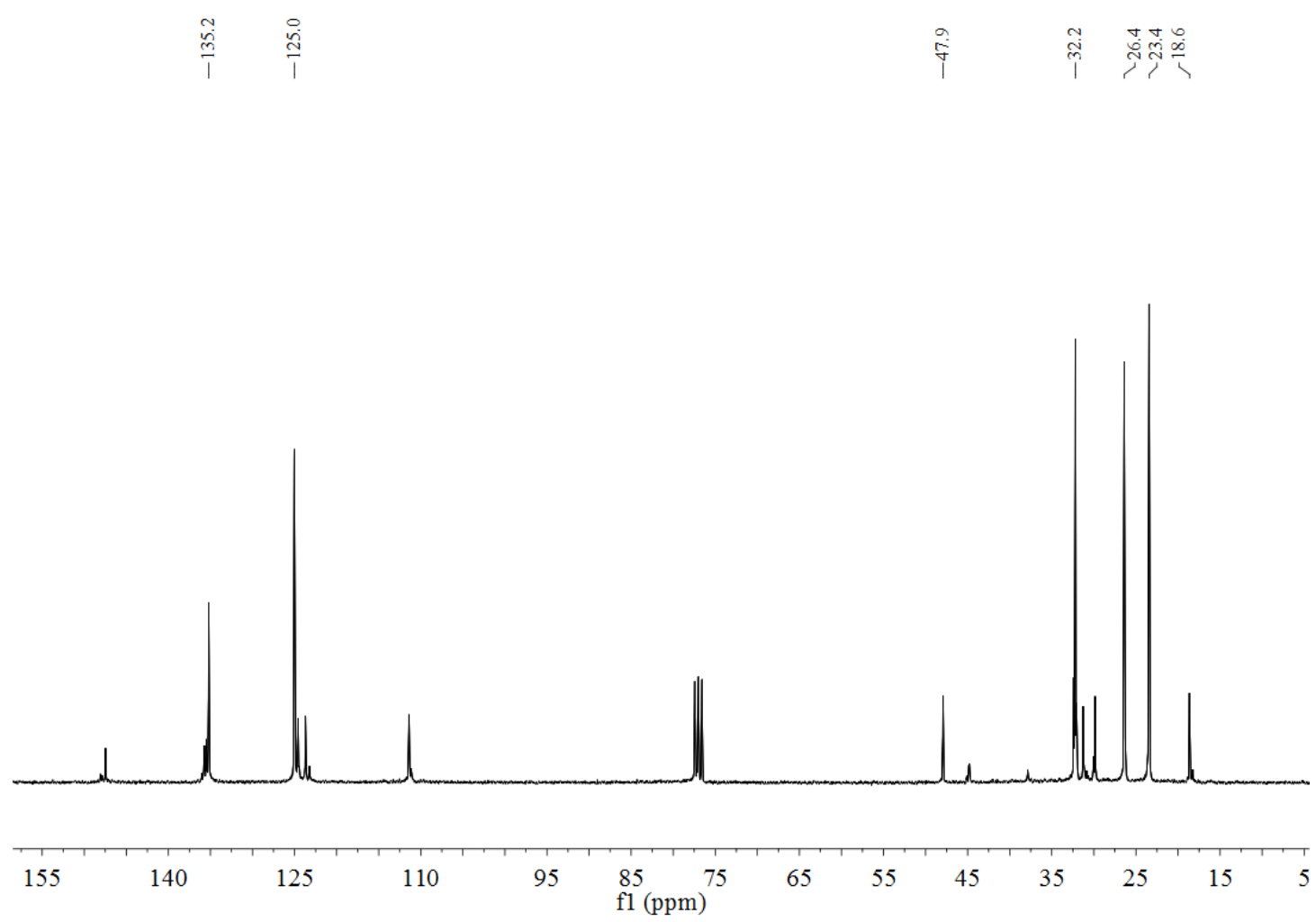

Figure S28. ${ }^{13} \mathrm{C}$ NMR spectrum of polyisoprene for the entry 6 in Table 1 (scan 8000 times). No 1,4-trans-polymer was observed. 


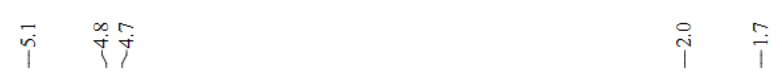

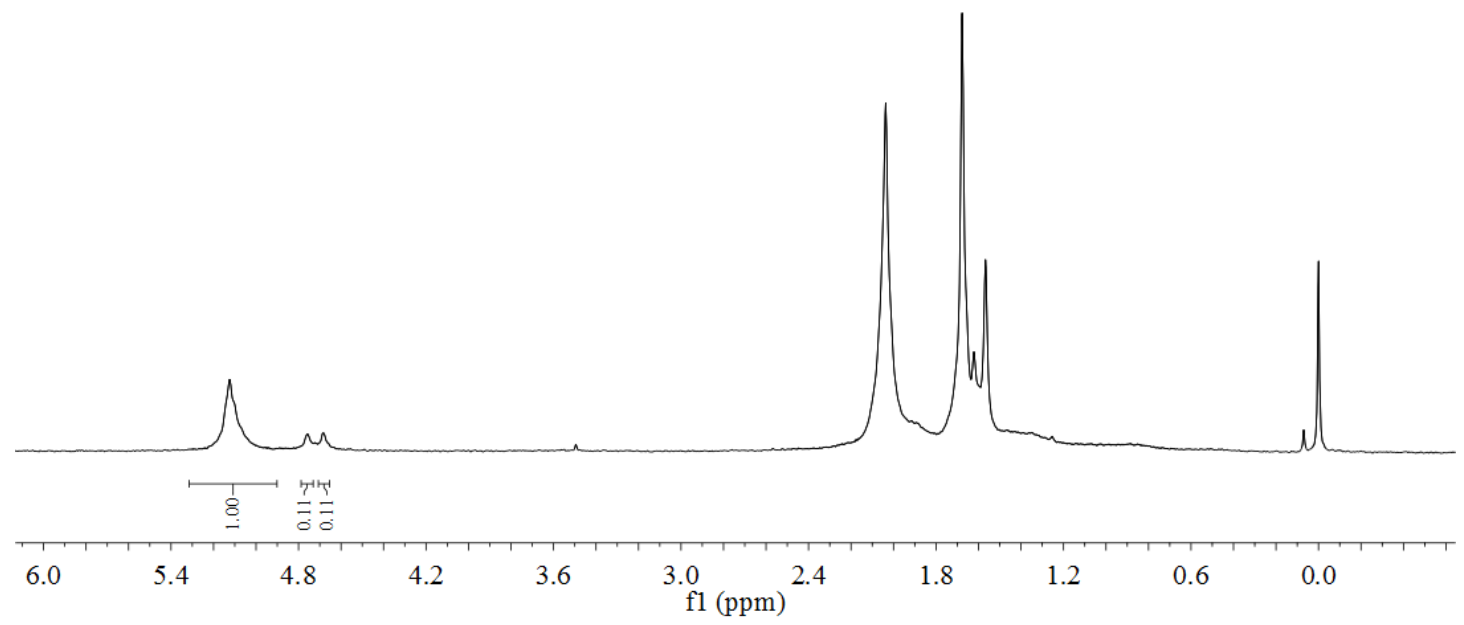

Figure S29. ${ }^{1} \mathrm{H}$ NMR spectrum of polyisoprene for the entry 7 in Table 1.
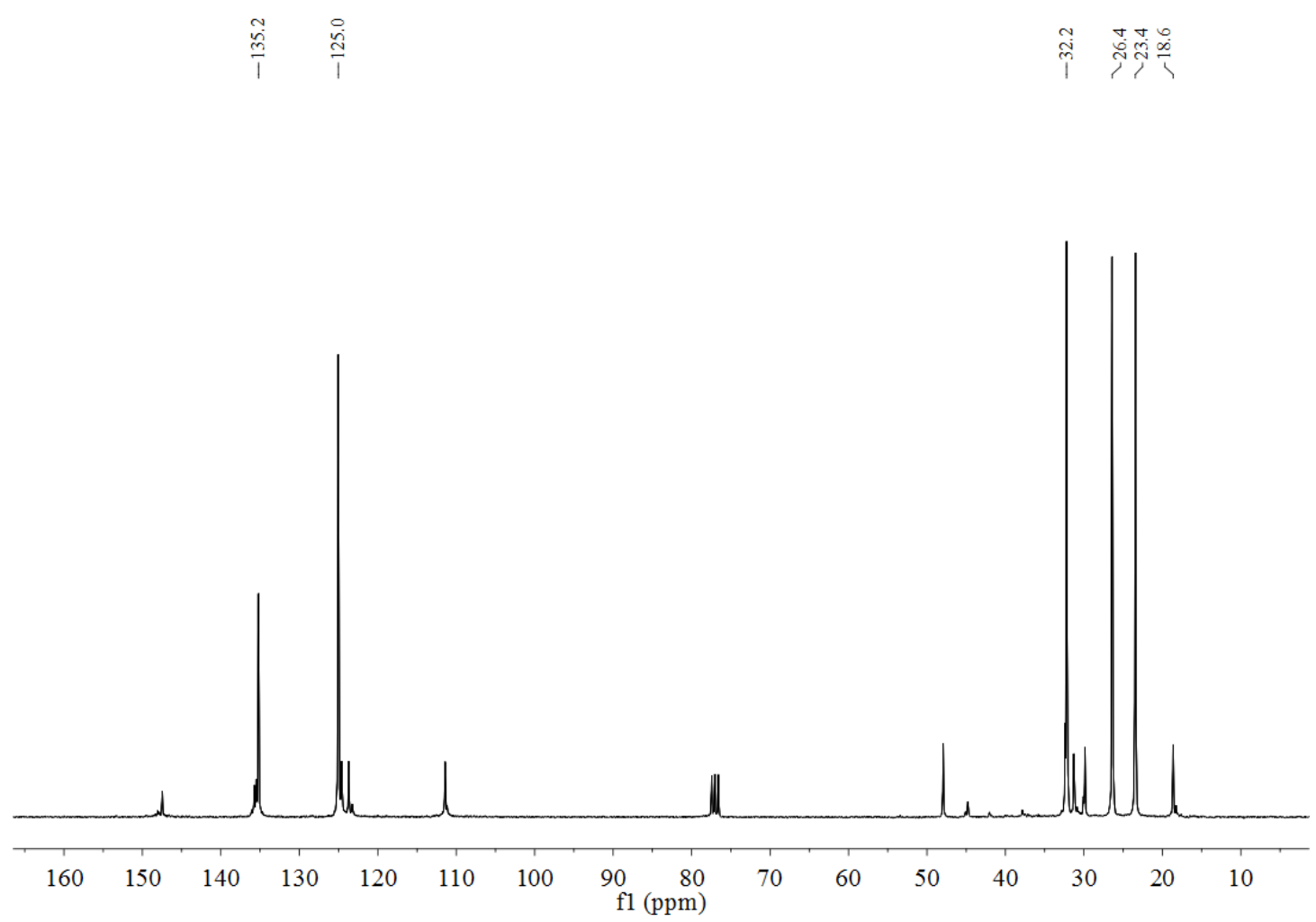

Figure S30. ${ }^{13} \mathrm{C}$ NMR spectrum of polyisoprene for the entry 7 in Table 1 (scan 8000 times). No 1,4-trans-polymer was observed. 


$$
\bar{i} \text { †⿺辶一 }
$$

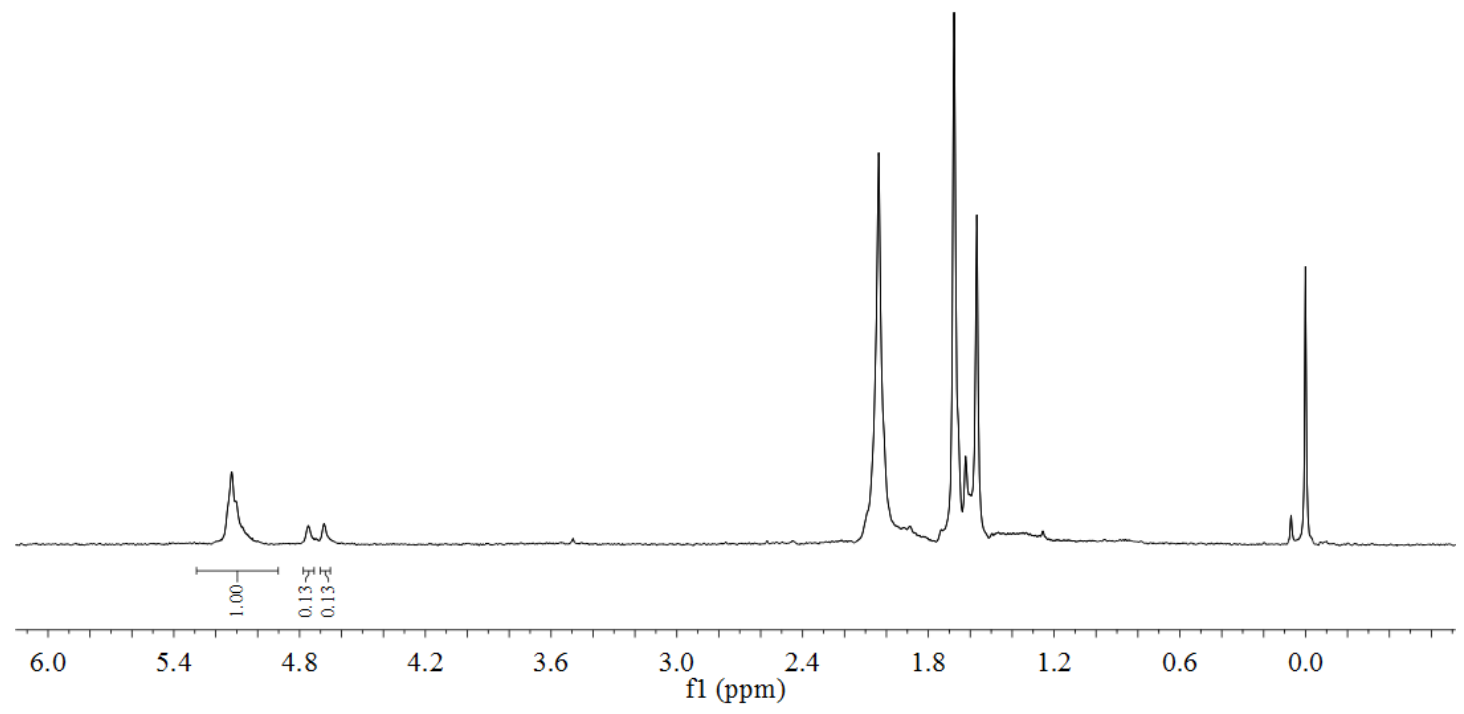

Figure S31. ${ }^{1} \mathrm{H}$ NMR spectrum of polyisoprene for the entry 8 in Table 1.

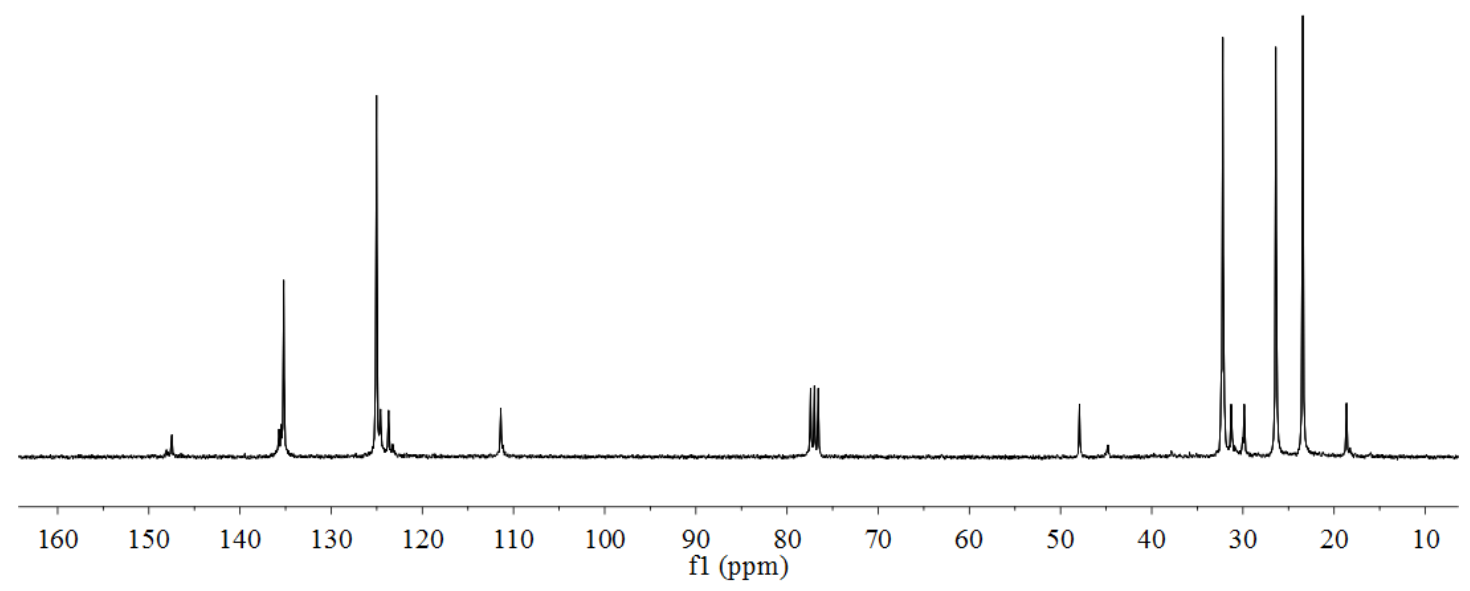

Figure S32. ${ }^{13} \mathrm{C}$ NMR spectrum of polyisoprene for the entry 8 in Table 1 (scan 8000 times). No 1,4-trans-polymer was observed. 


$$
\overline{\text { i }} \stackrel{\infty}{i} \dot{r} i
$$

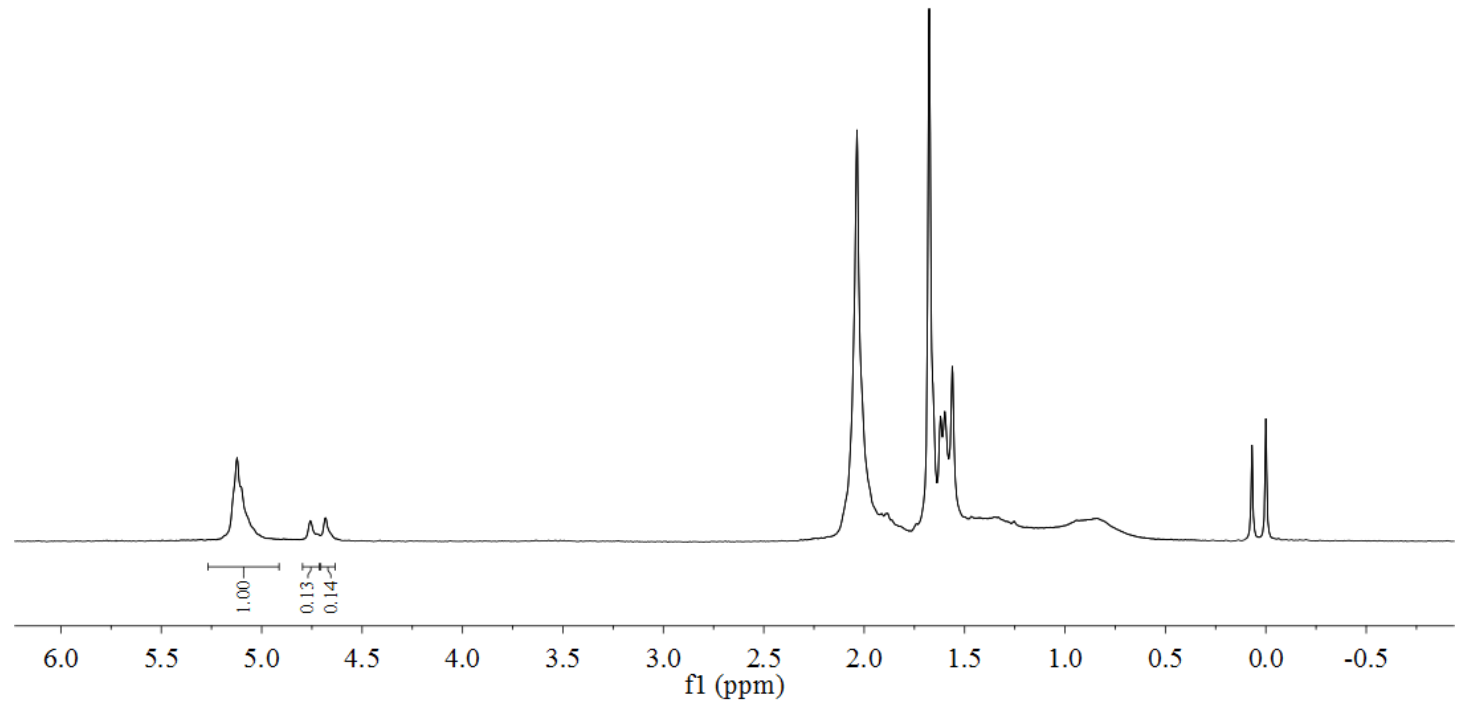

Figure S33. ${ }^{1} \mathrm{H}$ NMR spectrum of polyisoprene for the entry 9 in Table 1.

$$
\text { 采 }
$$
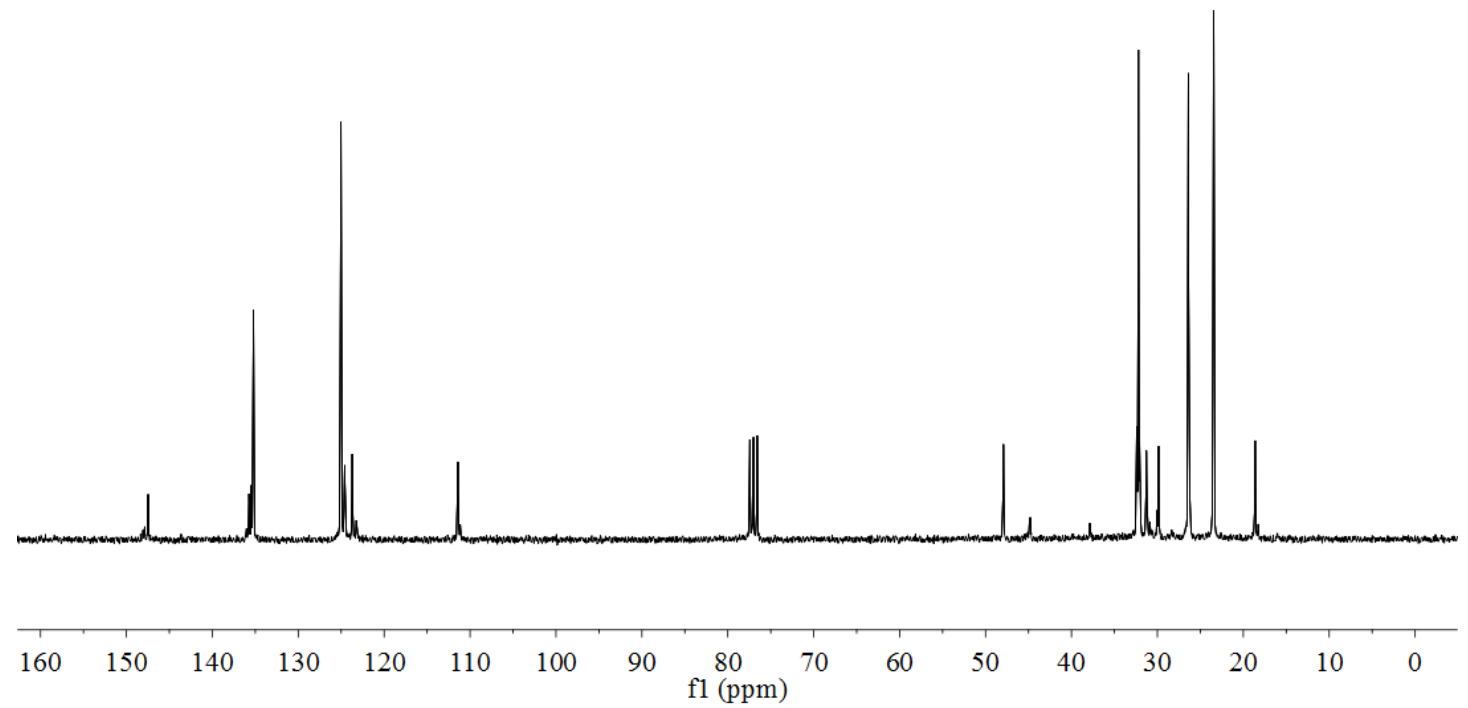

Figure S34. ${ }^{13} \mathrm{C}$ NMR spectrum of polyisoprene for the entry 9 in Table 1 (scan 8000 times). No 1,4-trans-polymer was observed. 


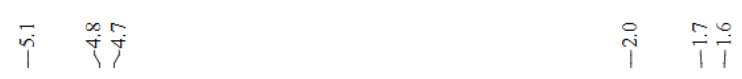

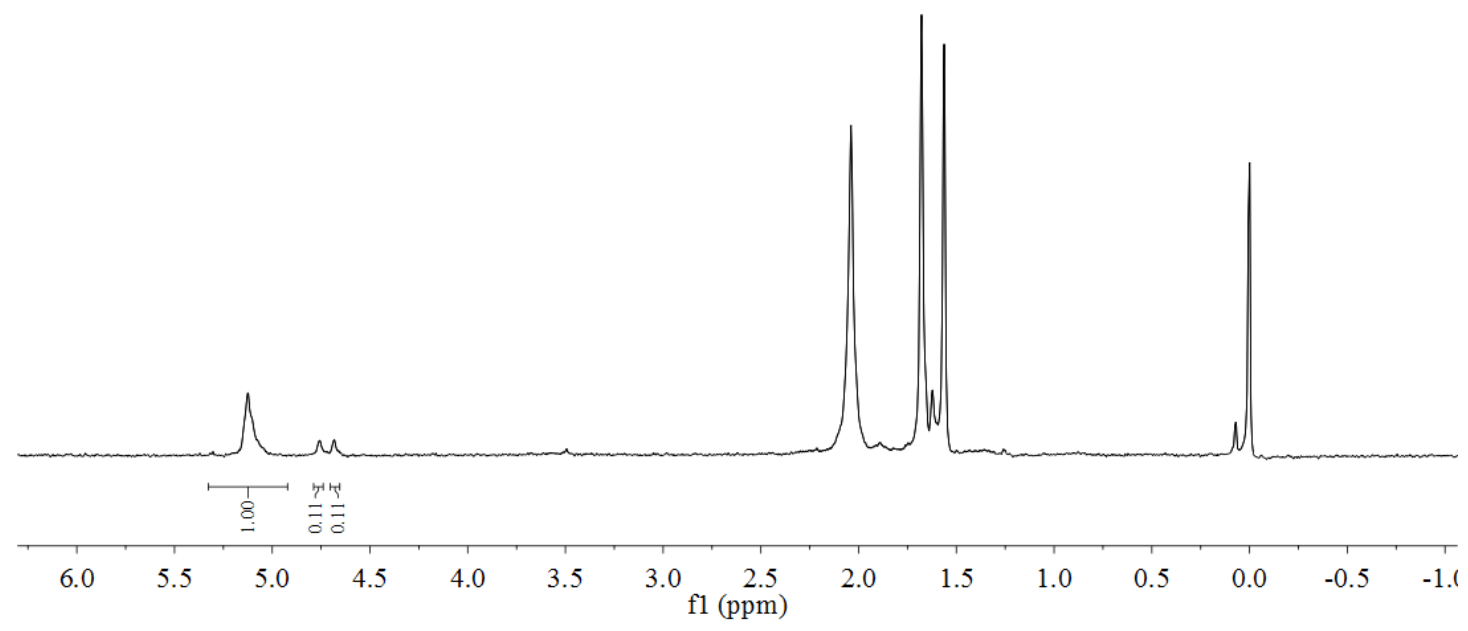

Figure S35. ${ }^{1} \mathrm{H}$ NMR spectrum of polyisoprene for the entry 10 in Table 1.

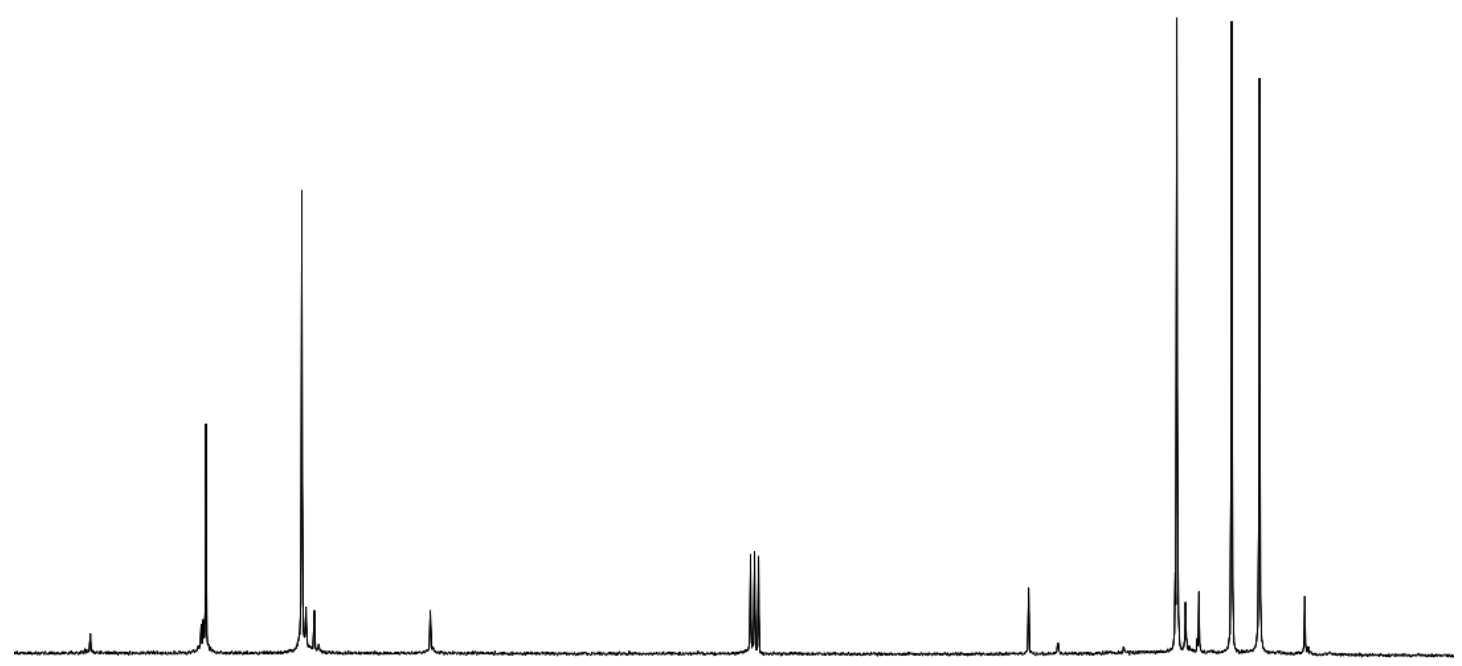

$\begin{array}{lllllllllllll}55 & 140 & 125 & 110 & 95 & \begin{array}{r}85 \\ \mathrm{f1}(\mathrm{ppm})\end{array} & 65 & 55 & 45 & 35 & 25 & 15 & 5\end{array}$

Figure S36. ${ }^{13} \mathrm{C}$ NMR spectrum of polyisoprene for the entry 10 in Table 1 (scan 8000 times). No 1,4-trans-polymer was observed. 


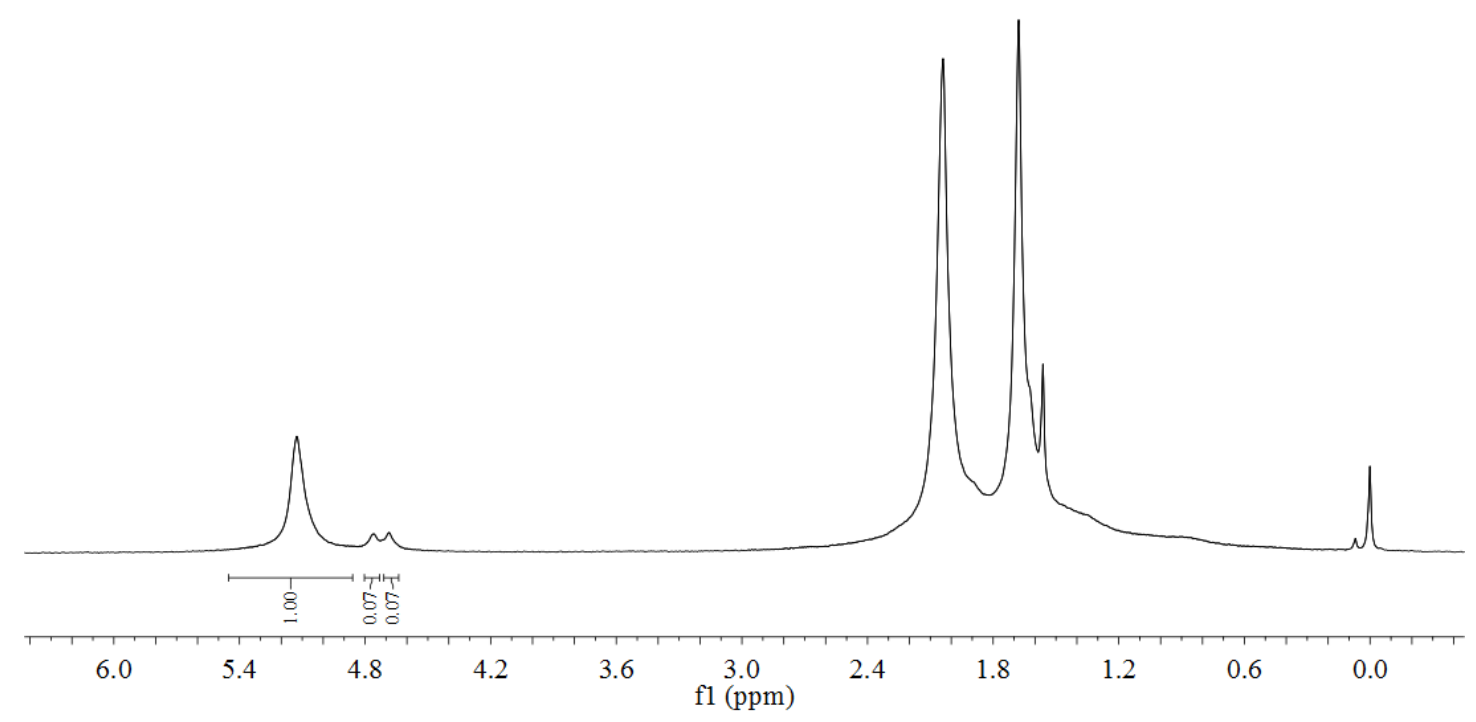

Figure S37. ${ }^{1} \mathrm{H}$ NMR spectrum of polyisoprene for the entry 11 in Table 1.

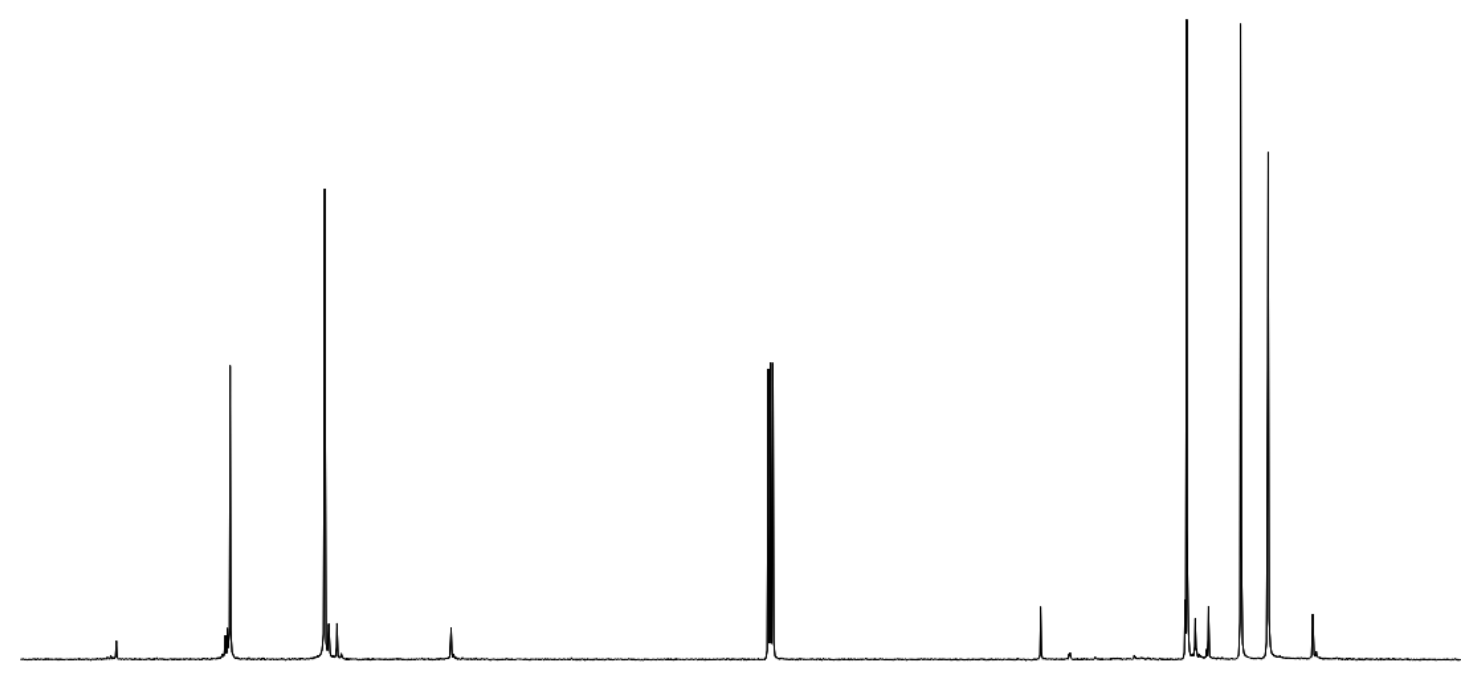

155 140 125 110 $95 \quad 85 \quad 75$

Figure S38. ${ }^{13} \mathrm{C}$ NMR spectrum of polyisoprene for the entry 11 in Table 1 (scan 10000 times). No 1,4-trans-polymer was observed. 


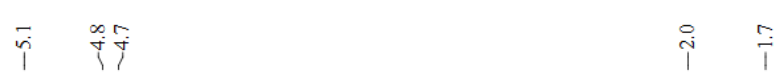

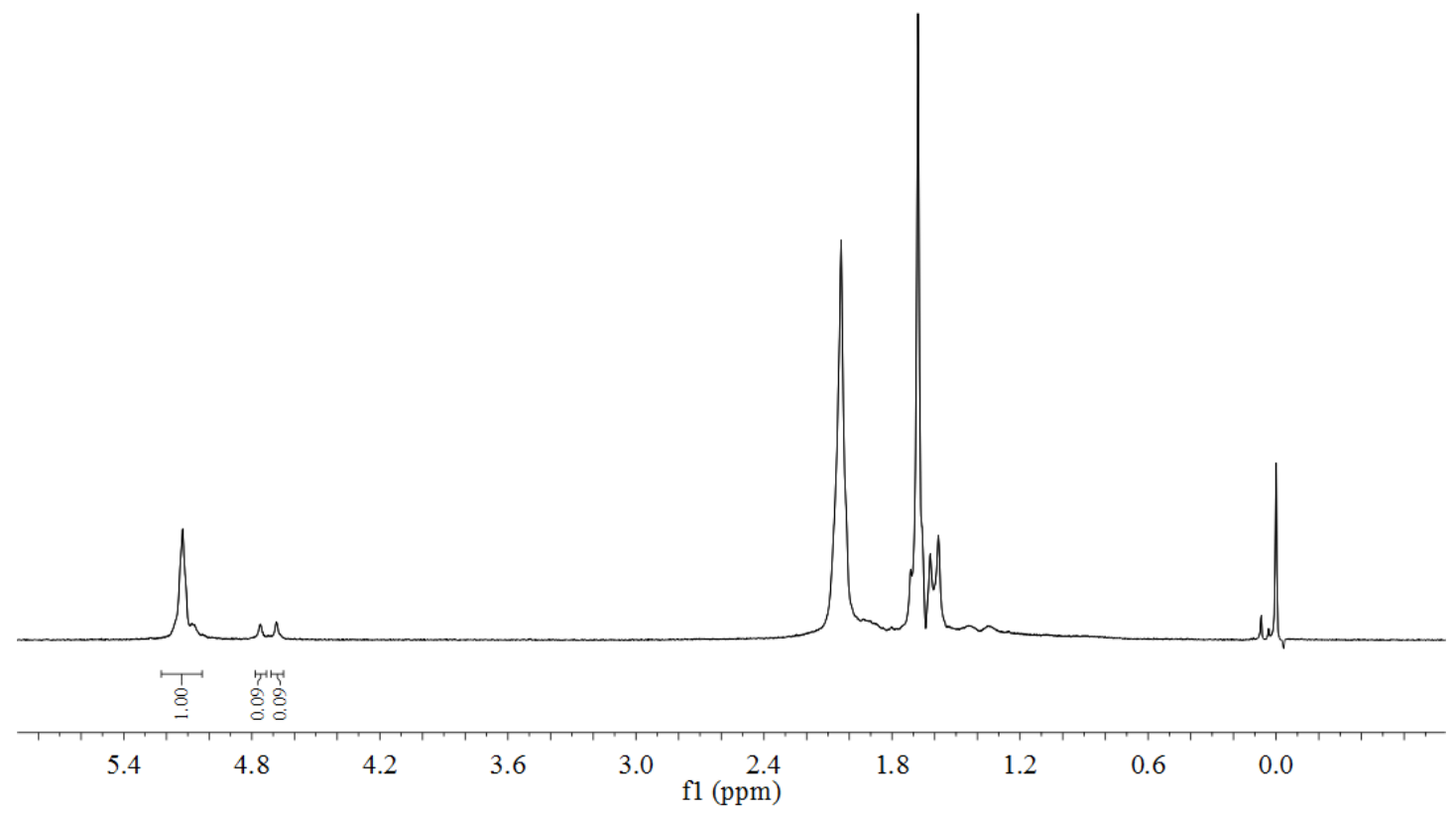

Figure S39. ${ }^{1} \mathrm{H}$ NMR spectrum of polyisoprene for the entry 12 in Table 1.

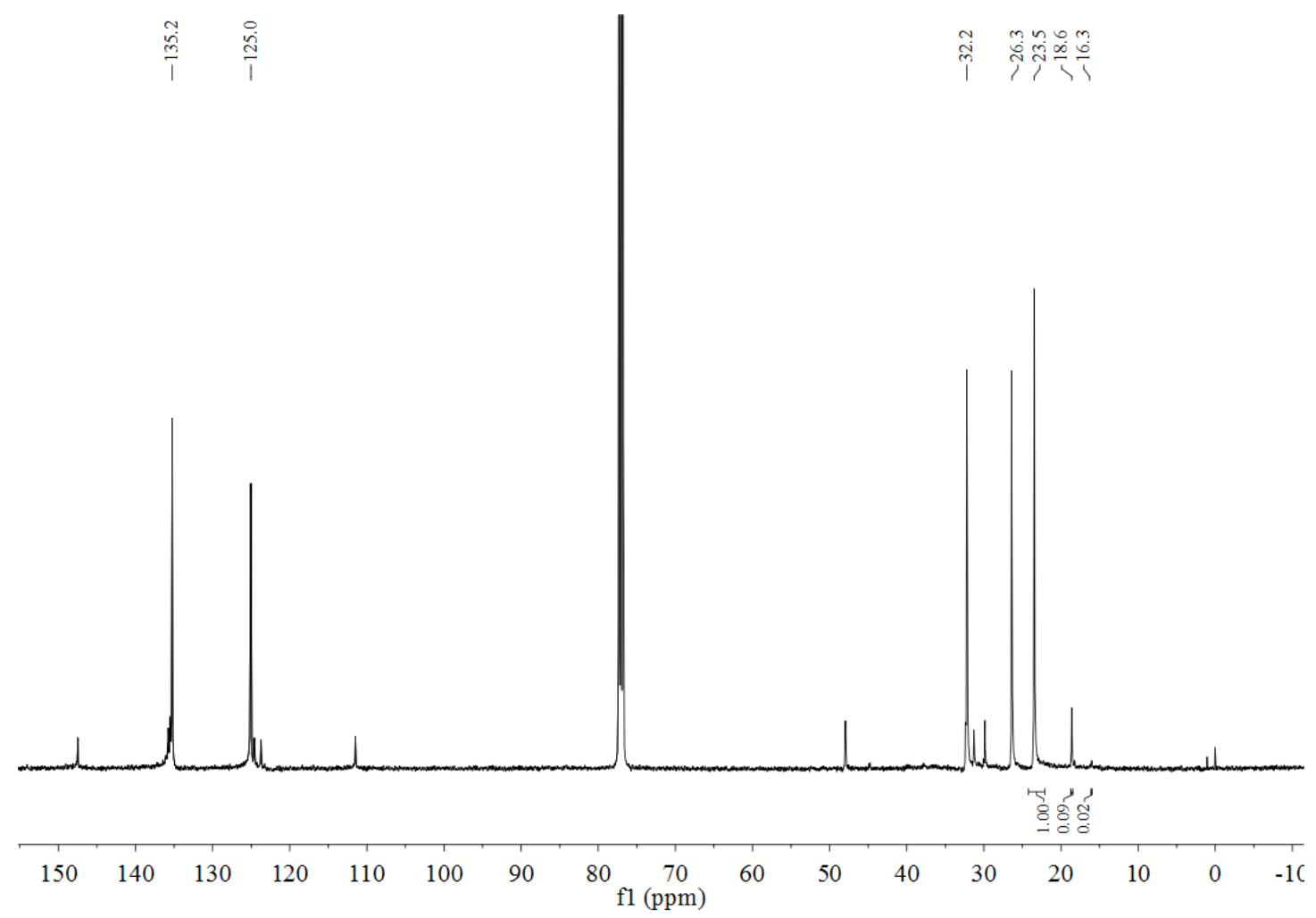

Figure S40. ${ }^{13} \mathrm{C}$ NMR spectrum of polyisoprene for the entry 12 in Table 1 (scan 4000 times). 


$$
\bar{i} \stackrel{\infty}{i} \dot{i} \quad \text { i }
$$

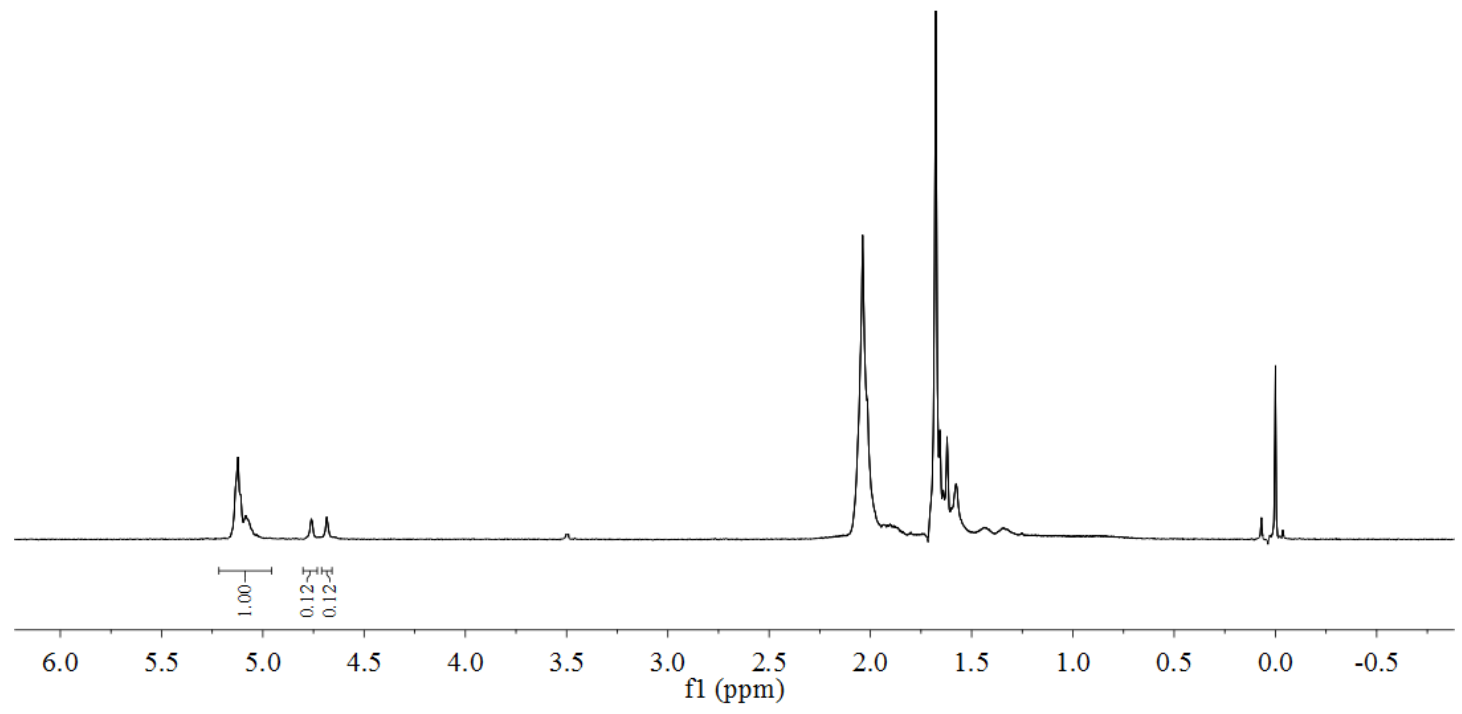

Figure S41. ${ }^{\mathbf{H}} \mathrm{H}$ NR spectrum of polyisoprene for the entry 13 in Table 1.

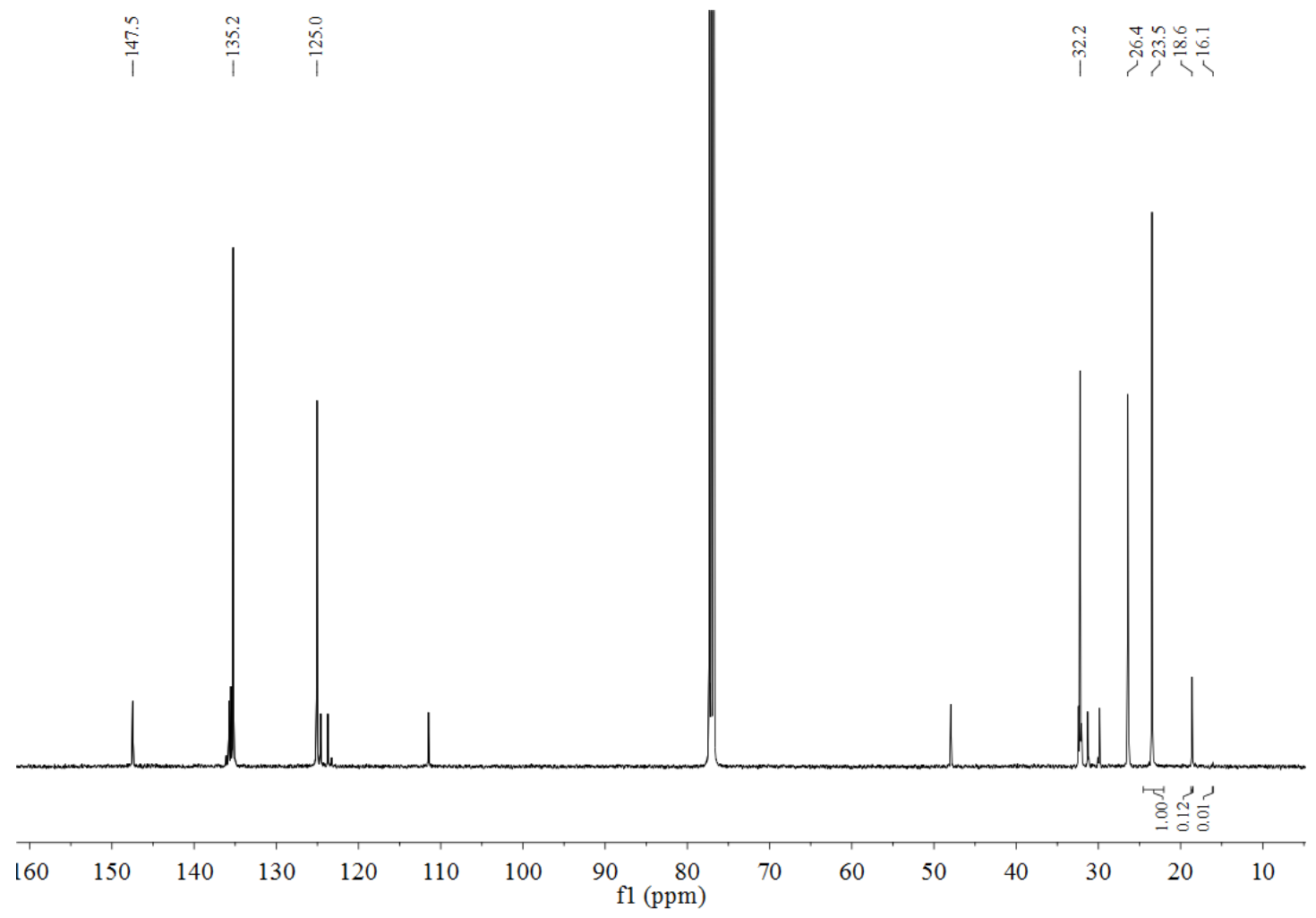

Figure S42. ${ }^{13} \mathrm{C}$ NMR spectrum of polyisoprene for the entry 13 in Table 1 (scan 6144 times). 